\title{
Biyoklimatik Konfor ve Arazi Kullanımı Arasındaki illişkinin CBS ve UA Teknikleri Kullanılarak İncelenmesi: İzmir îli Örneği
}

\author{
Elif ERKEK ${ }^{1}$, Neşe BAŞARAN ${ }^{2}$, Rutkay ATUN ${ }^{3}$, Özge KALAYCI ${ }^{4}$, Hande LAMBA ${ }^{5}$, Ayça ÖNER ${ }^{6}$, Saye \\ Nihan ÇABUK ${ }^{7}$, Hakan UYGUÇGiL ${ }^{8}$, Balca AĞAÇSAPAN ${ }^{*}$ \\ 1,2,3,4,5,6,9 Eskişehir Teknik Üniversitesi, Lisansüstü Eğitim Enstitüsü, Uzaktan Algılama ve Coğrafi Bilgi Sistemleri ABD, \\ Eskişehir. \\ ${ }^{7,8}$ Eskişehir Teknik Üniversitesi, Yer ve Uzay Bilimleri Enstitüsü, Jeodezi ve Coğrafi Bilgi Teknolojileri A.D.
}

*Sorumlu yazar e-posta: ${ }^{9}$ bagacsapan@eskisehir.edu.tr
1eliferkek@eskisehir.edu.tr
222592639390@eskisehir.edu.tr
${ }^{3}$ rutkayatun@eskisehir.edu.tr
${ }^{4}$ ozgekalayci@eskisehir.edu.tr
${ }^{5}$ handelamba@eskisehir.edu.tr
${ }^{6}$ aoner@eskisehir.edu.tr
${ }^{7}$ sncabuk@eskisehir.edu.tr
${ }^{8}$ uygucgil@eskisehir.edu.tr

Geliş Tarihi: 19.10.2019 Kabul Tarihi: 22.02.2020

\begin{abstract}
ORCID ID: https://orcid.org/0000-0001-5610-6902
ORCID ID: https://orcid.org/0000-0002-4381-3867

ORCID ID: https://orcid.org/0000-0001-5707-9491

ORCID ID: https://orcid.org/0000-0001-9959-2058

ORCID ID: https://orcid.org/0000-0001-5364-6794

ORCID ID: https://orcid.org/0000-0002-8873-5823

ORCID ID: https://orcid.org/0000-0001-9504-0002

ORCID ID: https://orcid.org/0000-0003-4859-2271

ORCID ID: https://orcid.org/0000-0003-3100-0129
\end{abstract}

Öz

Bu çalışmanın amacı, İzmir şehrinde biyoklimatik konfor ile arazi kullanımı arasındaki ilişkinin coğrafi bilgi sistemleri ve uzaktan algılama teknolojileri kullanılarak incelenmesidir. Bu çerçevede, İzmir şehrinde 1990, 2000, 2006, 2012 ve 2018 yıllarındaki biyoklimatik koşulların yine aynı yıllardaki arazi kullanımıyla olan ilişkilerinin mevsimlik ve yılık periyotta değerlendirilmesi hedeflenmiştir. Biyoklimatik Anahtar kelimeler Arazi kullanım değişimi; Biyoklimatik konfor; Fizyolojik Eşdeğer Sıcaklık (FES); Coğrafi Bilgi Sistemleri; Uzaktan algılama. konfor bölgeleri belirlenirken insanın fizyolojik özelliklerini de dikkate alan Fizyolojik Eşdeğer Sıcaklık (FES) indeksi kullanılmıştır. Elde edilen değerlerin deniz seviyesindeki alansal dağılımının hesaplanmasında uzaklığın tersiyle ağırlıklandırma (Inverse Distance Weighting - IDW) yöntemi tercih edilmiştir. Yüksekliğe bağlı FES değerleri elde edilmiştir ve biyoklimatik konfor haritaları oluşturulmuştur. CORINE arazi örtüsü verilerinin olduğu yıllar referans alınarak üretilen biyoklimatik konfor haritalarının yıllarına göre kullanılarak arazi kullanım haritaları oluşturulmuştur. Çalışma sonucunda, konfor bölgelerinin büyük bir çoğunluğunun tarım alanlarından ve daha sonra sırasıyla doğal ve yarı doğal alanlardan, orman alanlarından ve yerleşim yerlerinden oluştuğu gözlemlenmiştir. Orman alanlardaki sıcaklık farkının toprak alanlara göre daha az olmakla birlikte kentsel ısı adalarına kıyasla daha fazla olduğu ve şehirde nem miktarının oldukça yüksek olması ve kent merkezinde gözlenen çarpık kentleşme nedeniyle rüzgârın kenti soğutma etkisinin kullanılamadığı tespit edilmiştir.

\section{Investigation of the Relationship Between Bioclimatic Comfort and Landuse By Using GIS and RS Techniques: A Case Study Of Izmir}

\footnotetext{
Keywords

Land use change;

Bioclimatic comfort;

Physiological

Equivalent

Temperature (PET);

Geographic

information

systems; Remote

sensing.
}

\begin{abstract}
The aim of this study is to investigate the relationship between bioclimatic comfort and land use in İzmir by using geographical information systems and remote sensing technologies. In this context, it is aimed to evaluate the relationship between the bioclimatic conditions of the years 1990, 2000, 2006, 2012 and 2018 with the use of land in the same years in the province of izmir in seasonal and annual periods. Physiological Equivalent Temperature (PET) index, which takes into consideration the physiological characteristics of human, was used when determining bioclimatic comfort zones. Inverse Distance Weighting (IDW) method was preferred in the calculation of the spatial distribution of the obtained values at sea level. Height-dependent PET values were obtained and bioclimatic comfort maps were generated. Land use maps were created by using the bioclimatic comfort maps produced by reference to the years with CORINE land cover data. As a result of the study, it was observed that the vast majority
\end{abstract}


of the comfort zones consisted of agricultural areas and then natural and semi-natural areas, forest areas and settlements, respectively. It has been determined that the temperature difference in forest areas is less than the land areas, but it is more than urban heat islands and the city's cooling effect cannot be used due to the high humidity in the city and the distorted urbanization observed in the city center.

(C) Afyon Kocatepe Üniversitesi

\section{Giriş}

İklim, geçmişten günümüze kadar insanın yerleşme, barınma, beslenme, sağlık gibi günlük yaşam döngüsünü oluşturan gereksinimlerini yönlendirmesinde etkili olmuştur. Günlük yaşam rutinini etkileyen iklim kavramı,insanlar tarafından yüzyıllar boyunca daha iyi kavranmaya çalışılmıştır.Insan ile iklim arasında ilişki kuruldukça, insanların belli şartlarda kendilerini fizyolojik ve ruhsal olarak daha sağlıklı ve dinç hissettikleri görülmüştür. Buna bağlı olarak biyoklimatik konfor kavramı, insanı en az miktarda enerji harcayarak çevresine uyum sağladığı koşullar olarak tanımlanmaktadır (Özyavuz, 2017). Biyoklimatik konfor durumunun belirlenmesinde sıcaklık, nem ve rüzgar parametreleri değerlendirilmektedir (Topay ve Yılmaz, 2004).

Biyoklimatik konforun insan ve diğer canlı türleri üzerindeki etkisi nedeniyle,özellikle planlama ve tasarım süreçlerindeiçin önemli bir girdidir.. Zira, çoğunlukla çevreyle uyumlu ve sürdürülebilir yaşam alanları oluşturmak için gerçekleştirilen fiziksel planlama ve tasarım süreçlerinde, çevresel ve kültürel unsurlarkorunurken insanlar için de optimum yaşam şartlarının sağlanmasına odaklanılmaktadır. Bu kapsamda, iklimsel faktörlerin insanın daha konforlu bir yaşam sürmesini sağlayacak biçimde değerlendirilmesi ve planlama girdisi haline getirilmesi önemlidir. Benzer şekilde, mevcut arazi kullanımı ve fiziksel özelliklerin iklim üzerindeki etkisi de son derece önemli olup, sürdürülebilir planlama ve tasarımda göz önüne alınması gereken ölçütler arasında yer almaktadır. Dolayısıyla, iklim parametreleriyle fiziksel özelliklerin birbiri üzerindeki etkilerinin araştırılması, sürdürülebilir mekânların oluşturulmasında gerekli olan aşamalardan biridir. Bu bağlamda, bu çalışma kapsamında CORINE arazi örtüsü verilerinin olduğu yıllar referans alınarak
İzmir şehri bütünündeki biyoklimatik konforun 1990, 2000, 2006, 2012 ve 2018 yılları için belirlenerek aynı yıllardaki biyoklimatik konfora uygun alanların arazi kullanımlarıyla olan ilişkilerinin değerlendirilmesi amaçlanmıştır. Böylelikle, fiziksel planlama kararlarının insan için konforlu zonların oluşturulmasındaki rolünün tartışılması ve bu sayede sonraki planlama süreçleri için yol gösterici çıktıların elde edilmesi hedeflenmiştir. Bu bu amaç ve hedefler doğrultusunda, öncelikle literatür araştırması gerçekleştirilerek biyoklimatik konforun hesaplanması ve meteorolojik parametrelerin insanlar üzerindeki etkilerinin incelenmesine yönelik ulusal ve uluslararası çalışmalar belirlenmiştir. Bu çalışmalardan başlıcaları ve çalışmalar kapsamında kullanılan yöntem ile elde edilen temel çıktılar aşağıda özetlenmiştir:

- Kestane ve Ülgen (2013), yaptıkları çalışmada İzmir'deki 11 meteoroloji istasyonundan 20 yıl için saatlik sıcaklık, bağıl nem ve rüzgâr hızı verilerini kullanarak önce saatlik hissedilen sıcaklık, ardından bu hesaplarla aylık ortalama hissedilen sıcaklık değerlerini hesaplamışlar, Simple Kriging Prediction Map yöntemiyle çalışma alanı için hissedilen sıcaklık haritaları oluşturmuşlardır. Daha sonra 12 ay için oluşturulan hissedilen sıcaklık haritalarından ortalama alınarak yıllık hissedilen sıcaklık haritasına ulaşımıştır. En düşük ve en yüksek sıcaklık değer aralığını 5 eşit konfor bölgesine ayırmışlar ve yeniden sınıflandırma yaparak biyoklimatik konfor haritaları oluşturmuşlardır. Haritaların yorumlanmasıyla yerleşimin yoğun olduğu bölgelerde konforun azaldığı, kırsal alanlara doğru gittikçe konforun arttığı sonucuna ulaşmışlardır (Kestane ve Ülgen, 2013).

- Türkoğlu, Çalışkan, Çiçek ve Yılmaz (2012) tarafından yapılan çalışmada Ankara kent merkezinin biyoklimatik konfor alanlarının mekânsal ve zamansal dağılımının incelenmesinde farklı arazi 
dokusunda bulunan meteoroloji istasyonları 20012010 yıllarına ait sıcaklık, rüzgâr hızı, küresel solar radyasyon ve bağıl nem verileri toplanmıştır. İstasyonlardan toplanan bu veriler ile RayMan yazııımı kullanılarak Fizyolojik Eşdeğer Sıcaklık(FES)(Physiological Equivalent Temperature (PET)) değerleri hesaplanmıştır. Yapılan analizler ve hesaplamalar sonucunda Ankara kent merkezinde yüksek yapıların yoğun olarak bulunduğu alanlarda yıl boyunca FES değerinin gece boyunca yüksek ve ISI adalarının oluştuğu gözlemlenmiştir. Yine kent merkezinde yüksek yapıların yoğun olarak bulunduğu alanlarda temmuz sonu, ağustos başında aşırı sıcak ölçümler yapılmış ve FES değeri yüksek çıkmıştır (Türkoğlu vd., 2012).

- Çalışkan ve Türkoğlu (2012) benzer bir çalışma yaparak 69 istasyondan gelen 1975-2008 yılları arasına ait aylık ortalama hava sıcaklığı, rüzgâr hızı, küresel solar radyasyon, bulutluluk ve bağıl nem parametrelerini kullanmışlardır. Türkiye'nin biyoklimatik koşullarının alansal dağılımını termal konfor haritalarında göstermişlerdir. FES değerleri ile enlem, yükselti, denizellik parametreleri arasındaki ilişkiyi çoklu çizgisel regresyon ile, ilişkinin derecesini ise korelasyon analizi yaparak belirlemişlerdir. Analiz sonucunda Türkiye'nin güneyi, batı kıyı kuşağı ve vadi tabanı, ova gibi alçak alanlardaki FES değerlerinin diğer alanlardan $5^{\circ} \mathrm{C}$ $25^{\circ} \mathrm{C}$ daha yüksek olduğu belirtilmiştir. En yüksek FES değerlerinin mayıs-eylül ayları arasında güneydoğuda bulunan alçak alanlarda, ekim-nisan ayları arasında Akdeniz kıyısında görüldüğü; en düşük FES değerlerinin ise sıcak dönemde kuzeyde ve Kaçkar Dağları zirvelerinde, soğuk dönemde karasal ve yüksekte olan Büyük Ağrı Dağı zirvesinde görüldüğü belirtilmiştir (Çalışkan ve Türkoğlu, 2012). - $\quad$ Özşahin ve Eroğlu (2018) yaptıkları çalışma için Çorlu, Hayrabolu, Malkara, Marmara Ereğlisi, Muratlı, Saray, Şarköy ve Tekirdağ meteoroloji istasyonlarından hava sıcaklığı, buhar basıncı, rüzgâr hızı, bulutluluk verilerini ve MEB resmi istatistiklerinden ise çalışma alanındaki 2016 yılına ait okul ve öğrenci sayısı verilerini elde etmişlerdir. Bu verilerle aylık SET (Standart Efektif Sıcaklık), FES ve Tahmini Ortalama Isıl Şartlar (Predicted Mean Vote (PMV)) indislerini hesaplamışlardır. Daha sonra indis sonuçlarının yıllık ortalama değerlerini IDW
(Inverse Distance Weighted - Ters Mesafe Ağırlıklı Enterpolasyon) yöntemiyle dağıtmışlar ve konfor haritası oluşturmuşlardır. Analiz sonucunda çalışma alanının genelinde çok az serin termal algılama düzeyinin hâkimiyetinin görüldüğünü; okulların \%60'ının konforsuz, \%40'ının ise konforlu bölgede kaldığını, öğrencilerin \%69'unun (126.379) konforsuz, \%31'inin (56.450) konforlu bölgede eğitim gördüğünü belirlemişlerdir. Böylece çalışmayla biyoklimatik konforun eğitim faaliyetleri üzerinde dolaylı bir etkisinin bulunduğunu göstermişlerdir (Özşahin ve Eroğlu, 2018).

- Daneshvar vd. (2013) yaptıkları çalışmada İran'daki biyoklimatik konfor koşullarını FES ile analiz etmişlerdir. Kullanılan meteorolojik veriler 30 yıllık döneme ait (1976-2005) 48 istasyonun hava sıcaklığı, bağıl nem ve rüzgâr hızıdır. Bu veriler kullanılarak aylık FES değerleri elde edilmiştir. Çalışma sonucunda konforun optimum olduğu bölgeler yüksekliğin 1000 - 2000 metre, sıcaklığın 12 - $20{ }^{\circ} \mathrm{C}$ arasında ve de ortalama yağışın $200 \mathrm{~mm}$ altındaki bölgeler olduğu tespit edilmiştir (Daneshvar vd., 2013).

- $\quad$ Svensson vd. (2003) İsveç Göteborg'da kentsel bölgedeki biyoklimatik konfor alanlarını FES indeksi ve meteorolojik veriler aracılığıyla araştırmışlardır. Hem hava sıcaklığı hem de rüzgâr bölgesi haritaları, arazi kullanımı, yükseklik ve sahile olan uzaklık temelinde oluşturulmuştur. Svensson'un 2002'deki yaptığı çalışmaya dayanarak her bir hava sıcaklığı ve rüzgâr istasyonuna spesifik değerler tayin edilmiştir. Arazi kullanım alanları yoğun kentsel bölge, çok aileli binalar, müstakil ev alanları, yeşil alanlar ve sanayi bölgeleri olarak kategorize edilmiştir. Her arazi kullanım kategorisine Sverdrup güç yasasına göre farklı katsayılar verilmiştir. Yüksekliğe göre, arazi kullanım kategorileri 50 m'nin altında veya üstünde olan iki ana gruba ayrılmıştır. Elde edilen bulgulara göre İskandinavya'da konforu etkileyen ana sorun rüzgâr ve beraberindeki soğutma etkisi olduğu sonucuna varılmıştır. Buna ek olarak, en yüksek FES değerleri, merkezi yerleşim alanlarında, en düşük FES değerleri ise kıyı ve yeşil alanlarda bulunmuştur (Svensson vd., 2003).

- $\quad$ Tağıl ve Ersayın (2015) ise Balıkesir ilindeki termal biyoklimatik konforun mekânsal ve zamansal 
dağılımını yapmış ve konforun yıl içerisindeki mekânsal dağııımındaki değişimi sorgulamışlardır. Çalışmalarında Balıkesir ilinde insan yaşamı için termal konforun uygun olduğu alanların belirlenmesi amacıyla mevcut olan termal algıyı belirlemek için aylık termal konfor şartları analiz edilmiştir. Bu analiz için RayMan yazılımı kullanılarak aylık FES değerleri üretilmiş ve mekânsal dağılımı için IDW modeli kullanılmıştır. Yıllık FES değerlerinin çok az serin ve konforlu termal algılama derecelerine karşılık gelen $13,6^{\circ} \mathrm{C}-19,5^{\circ} \mathrm{C}$ değerleri arasında dağııım gösterdiği tespit edilmiştir (Tağıl ve Ersayın, 2015).

- Kantor ve Unger (2010) kentsel alandaki dinlenme yerlerinin termal konfor araştırmaları için bir metodoloji önermişlerdir. Belirledikleri üç dönem boyunca yarım saat aralıklarla saat 12.00 15.00 aralığında 6775 ziyaretçiyi haritalamışlardır. Ölçüm aralıklarındaki ısıl koşulları tanımlamak için FES'i alanın meteoroloji verileriyle hesaplamışlardır. Arazi kullanım modelinin termal koşullar ile ilişkilerini göstermek için verileri ArcView ile sayısallaştırıp işlemişlerdir. Hava sıcaklığı, bağıl nem, rüzgâr hızı ve termal radyasyon klimatik konforu etkileyen parametreler olarak alınmış ve bu faktörler FES ve OUTSET ile hesaplamışlardır. Ayrıca termal konforu öznel özelliklere de bağlı olduğu için ziyaretçilerin davranışsal uygulamaları da gözlemlenmiştir. Bu bilgilerin gelecekte, ölçülen meteorolojik parametrelerden konfor endekslerini hesaplamak veya incelenen alanın termal koşullarını simüle etmek için ENVI-Ray veya RayMan yazılımıyla alan modelini ayarlamak için faydalı olacağını belirtmişlerdir (Kántor ve Unger, 2010)

- Güçlü (2010), Edremit, Ayvalık, Dikili, İzmir, Çeşme, Kuşadası, Didim, Bodrum, Datça ve Marmaris'te bulunan meteoroloji istasyonlarında 1975 ve 2008 yılları arasında ölçülen hava sıcaklığı, bağıl nem ve rüzgâr hızı, güneşlenme süresi ve yağış miktarı verilerini kullanarak; TCI (Turizm İklim İndisi), THI (Sıcaklık Nemlilik İndisi) ve SSI (Yeni Yaz İndisi) incelemişlerdir. İnceleme sonucunda kıyı turizmi yönünden iklim konforu şartlarının en elverişli olduğu ayların mayıs, haziran ile eylül ve ekim ayları olduğu ve özellikle mayıs ayının ideale yakın değerlerde olduğu belirtilmiştir (Güçlü, 2010).
- $\quad$ Topay'ın (2007) yapmış olduğu çalışmada, Muğla ilinin biyoklimatik konforu 11 meteoroloji istasyonuna ait 1929 - 2000 yılları arası, haziran ve ekim ayları arasını kapsayan ortalama hava sıcaklığı, bağıl nem ve rüzgâr verileri kullanılarak CBS ortamında değerlendirilmiştir. Meteoroloji verileri ile IDW yöntemine göre aylık iklim haritaları oluşturulmuştur. Sonuç haritaları Olgyay'ın (1973) insan biyoklimatik konfor değerine göre konforlu ve konforsuz bölgeler olmak üzere 2 sınıfa ayrılmıştır. Elde edilen bulgulara göre Muğla ilinde en konforlu aylar haziran, ağustos ve eylül ayları olurken en konforlu alanlar ise ilin merkez ve kuzey kısımları olmuştur. Yine Topay, bu çalışmasına benzer olarak Yılmaz ile birlikte (2010) Muğla ilinin biyoklimatik konfor alanlarını belirlemişlerdir. Meteorolojik veriler rakım değeri 3-850 metre arasında değişmekte olan 10 meteoroloji istasyonundan toplanmıştır (Topay, 2007).

- $\quad$ Song ve $\mathrm{Wu}$ (2018) yüzey sıcaklığı (LST) ve rahatsızlık indeksi (Discomfort Index - DI) gibi parametreler aracılığıyla insanın ısı stresini uzaktan algılama yöntemleriyle araştırmışlardır. Çalışma $A B D^{\prime}$ nin Wisconsin eyaletinde yürütülmüştür. DI değerini elde etmek amacıyla, ilk olarak bu araştırmada kuru sıcaklık olarak kabul edilen LST'yi hava sıcaklığına bağlamak için deneysel modeller kurulmuştur. Daha sonra, kuru termometre sıcaklığı ve bağıl nemden ıslak hava sıcaklığı elde edilmiştir. Islak hava sıcaklığını hesaplamak için ise bağıl nem değerleri NARR'dan alınmıştır (North America Regional Reanalysis). Ardından, DI kuru ve ıslak hava sıcaklığından hesaplandığı için, uzamsal dağılımı LST ile karşılaştırılmıştır. LST, NDVI (Normalized Difference Vegetation Index) ve NDBI (Normalized Difference Built-up Index) hesaplamak için MODIS görüntüsü kullanılmıştır. Sonrasında, LST - NDVI NDBI ve DI, LST ve DI'nın mekânsal dağılımı karşılaştırmak için ve de DI'nın ISI stresini hesaplamada önemini göstermek için bunlar korelasyon analizine tabi tutulmuştur. Sonuçlar, bu araştırmada oluşturulan deneysel modele dayanarak hesaplanan hava sıcaklığının, mevcut çalışmalara kıyasla düşük RMSE değerleri ile oldukça doğru olduğunu göstermiştir. Öte yandan, DI'nın sıcak bir çevrede insan rahatsızlığını belirten daha önemli bir indikatör olduğu kanıtlanmıştır. Fakat, 
hesaplanan DI'nın doğruluğu LST'nin doğruluğuyla alakalıdır. Ayrıca, Dı'nın doğruluğunu kanıtlamak için de saha ölçümleri gerçekleştirilmemiş olup sonuçlar, tek bir ölçekte bir çalışma alanına dayandırılmıştır (Song ve Wu, 2018).

- $\quad$ Pawar, Mukherjee ve Shankar (2015) CBS kullanılarak belirli bölgelerdeki termal konfor değişikliğinin, duyarlı bina tasarımı stratejilerini de değiştirdiğini gösteren süreci ifade edilmiştir. Hindistan'da yaşanan çok çeşitli iklim değişikliklerini göstermek için yüksek çözünürlüklü enterpolasyonlu iklimsel veri alt kümesi kullanmışlardır. Mahoney Tablosu metodu ile altı iklim göstergesini hesaplamak için raster verileri CBS kullanarak türetmiş ve sınıflandırmışlardır. 8 grupta seçilen bina tasarım kriterlerini 62 termal konforlu tasarım bölgesini oluşturmak için üst üste getirmişlerdir. Hava sıcaklığı, bağıl nem ve yağış verileri kullanılarak termal konfor analizi ArcMap 10 ile yapılmıştır. Yapılan analizler sonucu konfor bölgeleri belirlenip, farklı iklimlere göre haritalandırılmıştır (Pawar vd., 2015).

Özetlenen biyoklimatik konfor araştırmaları doğrultusunda İzmir ilinde gerçekleştirilecek çalışmanın yöntemi vekullanılacak verilertespit edilmiştir. Çalışmada kullanılan materyaller ve uygulanan metot materyal ve metot bölümünde açıklanmıştır.

\section{Materyal ve Metot}

\section{1 Çalışma Alanı}

Çalışmanın materyallerinden biri olan çalışma alanı Türkiye'de yer alan İzmir ilidir. $12.007 \mathrm{~km}^{2}$ lik bir yüzölçümüne sahiptir ve $37^{\circ} 45^{\prime}$ ve $39^{\circ} 15^{\prime}$ kuzey paralelleri ile $26^{\circ} 15^{\prime}$ ve $28^{\circ} 20^{\prime}$ doğu meridyenleri arasında kalmaktadır (Demirtaş, 2007) (İzmir Büyükşehir Belediyesi, 2013) (Kara, 2017). Şekil 1'de çalışma alanı sınırları görülmektedir.

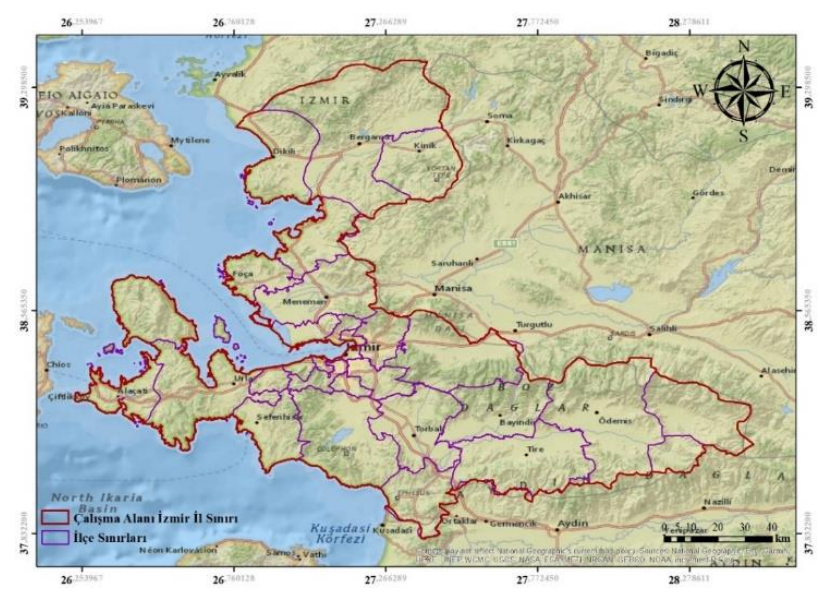

Şekil 1. Çalışma alanı.

Tarih boyunca farklı medeniyetlerin hâkimiyeti altında olan bölge, doğal ve kültürel miras değerleriyle önem arz etmektedir. Fakat 1950'li yıllardan sonra almakta olduğu yoğun göç ile birlikte hızlı bir kentleşme sürecine giren şehir düzensiz kentleşmeyi de beraberinde getirmiştir. Yıllar içinde kontrolsüz bir şekilde büyüyen kentte bugün $\mathrm{km}^{2}$ 'ye 360 kişi düşmektedir ve merkez bölgesi bu kalabalık nüfusu ile doğal büyüme eşiklerine ulaşmış bulunmaktadır.

İzmir şehri, Akdeniz ikliminin etkisi altında olup yaz mevsimini sıcak ve kurak, kış mevsimini ılık ve yağışlı geçirmektedir. Yapılan literatür araştırmalarına göre yıllara bağlı olarak şehrin rüzgâr yönünün ve mevsim sürelerinin değişmesi, saatte meydana gelen yağış miktarının artması, deniz seviyesinin yükselmesi vb. sorunları ile karşı karşıya kalan İzmir, Türkiye'de küresel iklim değişikliklerinin en fazla hissedileceği illerden biri olarak değerlendirilmektedir.

Çalışmanın bir diğer materyali kullanılan yazılımlardır. İzmir ili için FES indeksini hesaplanırken ArcGIS 10.6 yazılımı ile RayMan Pro kullanılarak biyoklimatik konfor haritasıoluşturulmuştur. Şekil 2'de gösterilen konfor zonu aralıklar Çizelge 1'deki bilgiler doğrultusunda belirlenerek çalışma alanında konfor zonları belirlenmiştir.

Çalışmada kullanılan konfor zonlarının limit değerleri literatür araştırması baz alınarak Şekil 2'deki gibi belirlenmiştir (Fröhlich \& Matzarakis, 2017) Lin, Matzarakis, Liu.,) (Makaremi, Salleh, Jaafar., 2011) ( Çalışkan \& Türkoğlu, 2014) 
Çizelge 1.Literatürde belirlenen konfor zonları.

\begin{tabular}{cll}
\hline PET $\left({ }^{\circ} \mathbf{C}\right)$ & Termal Algı & Fiziksel Stres Derecesi \\
\hline $\mathbf{>} 41$ & Çok Sıcak & Aşırı Isı Stresi \\
\hline $\mathbf{3 5 - 4 1}$ & Sıcak & Güçlü Isı Stresi \\
$\mathbf{2 9 - 3 5}$ & Ilık & Orta Isı Stresi \\
\hline $\mathbf{2 3 - 2 9}$ & Hafif Ilık & Hafif Isı Stresi \\
\hline $\mathbf{1 8 - 2 3}$ & Konforlu & Termal Stres yok \\
\hline $\mathbf{1 3 - 1 8}$ & Hafif Serin & Hafif Soğuk Stresi \\
\hline $\mathbf{8 - 1 3}$ & Serin & Orta Soğuk Stresi \\
\hline $\mathbf{4 - 8}$ & Soğuk & Güçlü Soğuk Stresi \\
\hline$\leq 4$ & Çok Soğuk & Aşırı Soğuk Stresi \\
\hline
\end{tabular}
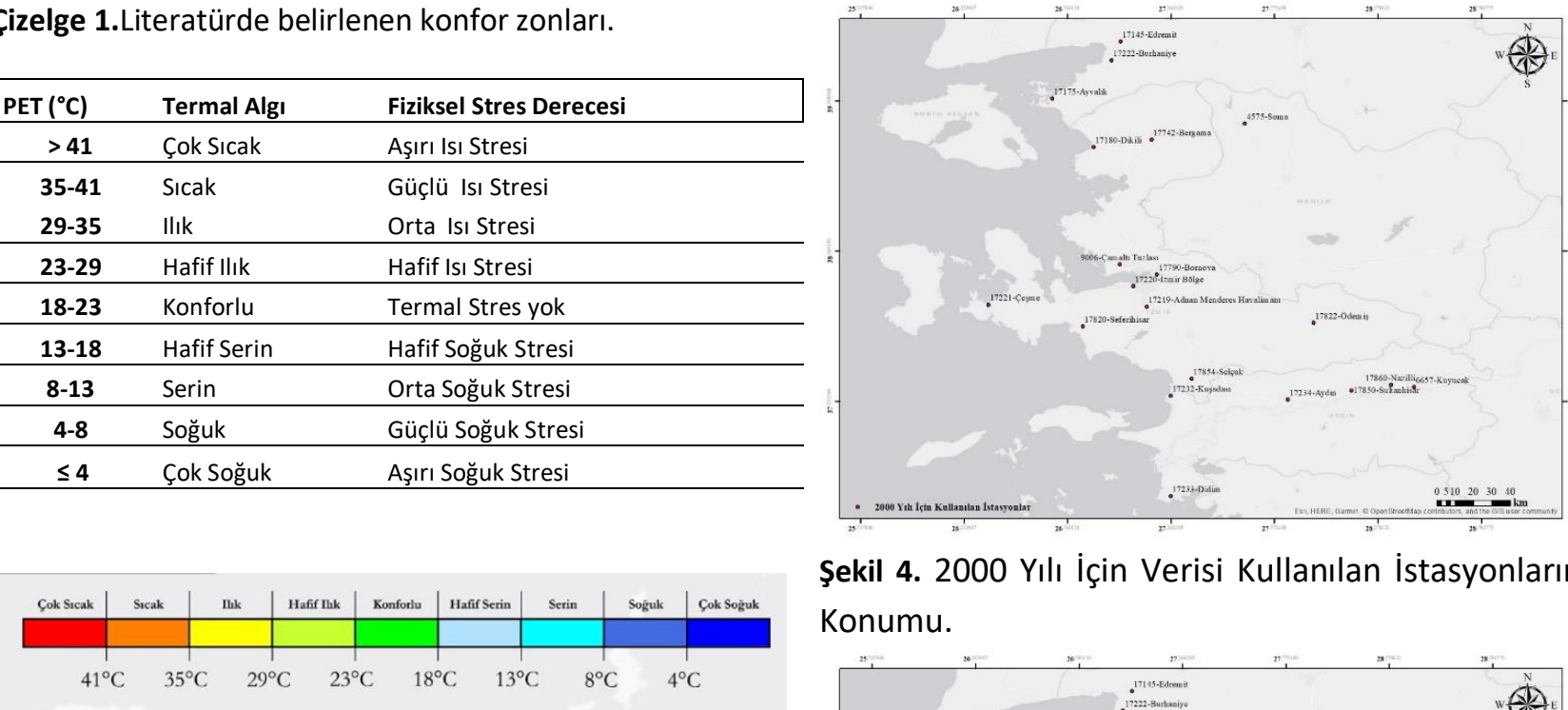

Şekil 2. Çalışma alanında tanımlanan konfor zonları

CORINE verilerine bağı arazi kullanım haritalarının oluşturulması için Erdas Imagine yazılımları kullanılmıştır.

Çalışmada kullanılan diğer veriler ve veri kaynakları şunlardır çalışmanın biyoklimatik konfor haritası oluşturma aşamasında kullanılan meteorolojik veriler, Meteoroloji 3. Bölge MüdürlüğüEskişehir'den elde edilen 1990, 2000, 2006, 2012 ve 2018 yıllarına ait günlük ortalama hava sıcaklığı, bağıl nem ve rüzgâr hızı verileridir. Şekil 3, Şekil 4, Şekil 5, Şekil 6 ve Şekil 7'da ilgili yıllara ait istasyonların konumları harita üzerinde gösterilmektedir.

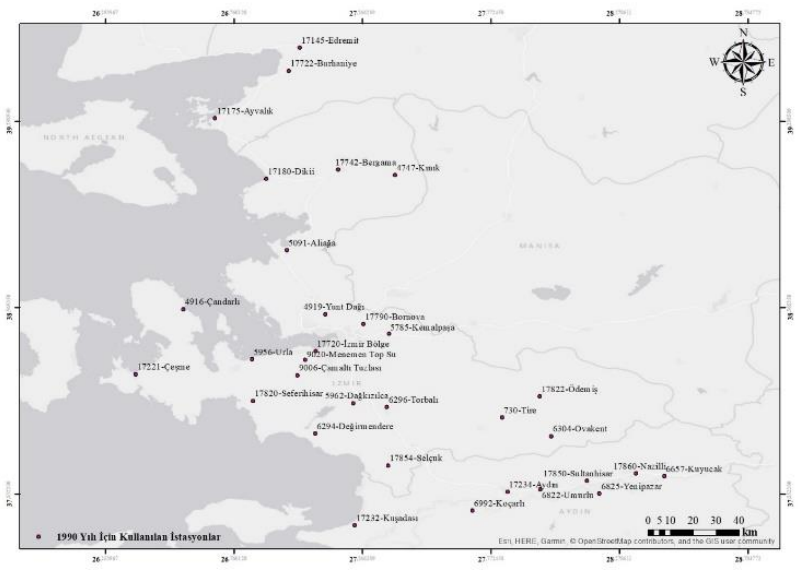

Şekil 4. 2000 Yılı İçin Verisi Kullanılan İstasyonların Konumu.

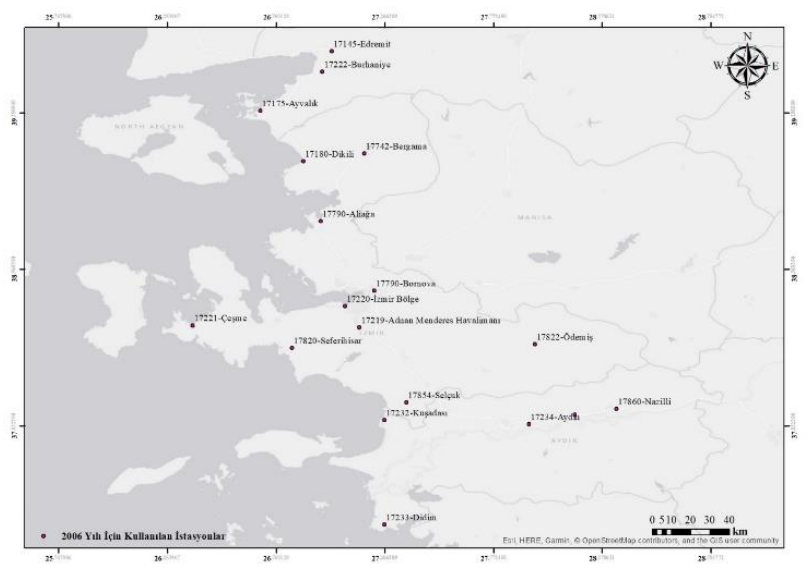

Şekil 5. 2006 Yılı İçin Verisi Kullanılan İstasyonların Konumu.

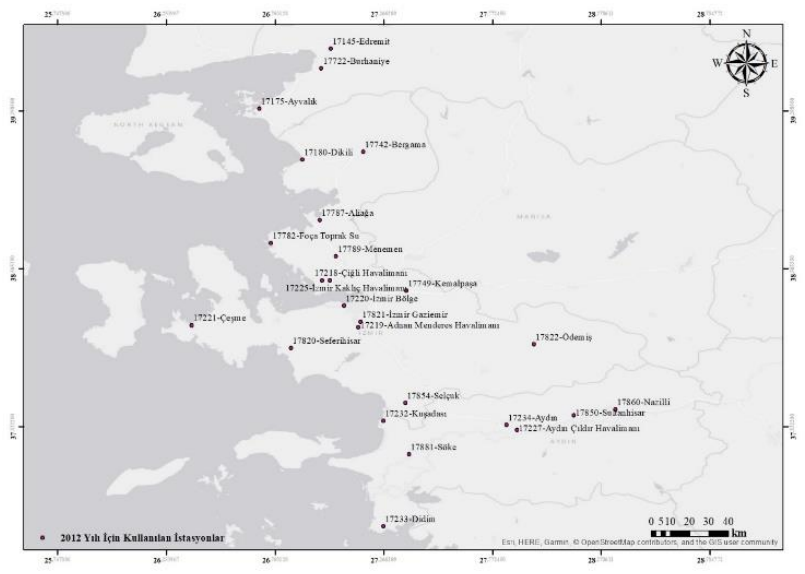

Şekil 6. 2012 Yılı İçin Verisi Kullanılan İstasyonların Konumu. 


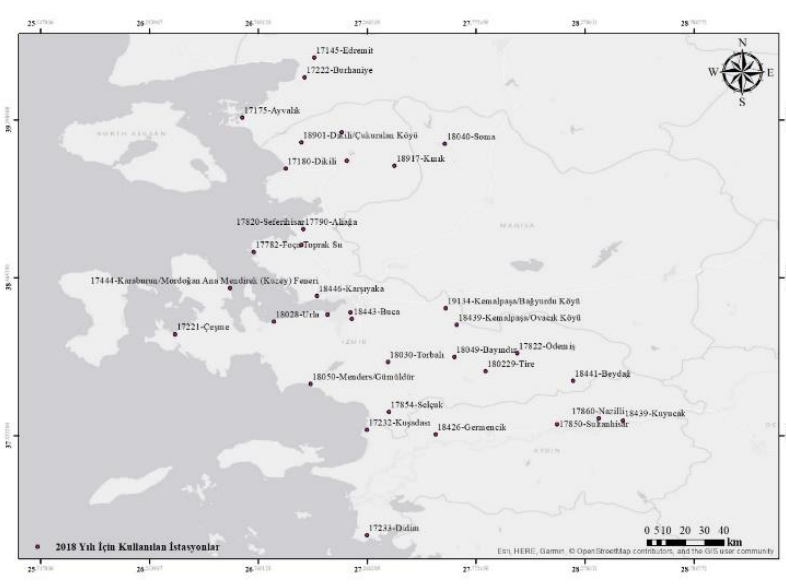

Şekil 7. 2018 Yılı İçin Verisi Kullanılan İstasyonların Konumu.

Verileri temin edilen meteorolojik istasyonların ayrıntılı bilgileri Çizelge 2'de verilmektedir. Bu aşamada sıcaklığı yüksekliğe bağıı dağıtma işleminde kullanılan veri ASTER-GDEM sayısal yükseklik modelidir. ASTER-GDEM, 83으 kuzey ve güney paralellerinde dünyayı kapsayacak şekilde ve $30 \mathrm{~m}$ çözünürlüklü olarak üretilerek, ilk versiyonu Haziran 2009'da ve ikinci versiyonu Ekim 2011'de kullanıcılara sunulmuştur $(1,2019)$.

Çizelge 2. Verileri temin edilen meteorolojik istasyonlar.

\begin{tabular}{|c|c|c|c|c|c|}
\hline ISTASYON NO VE ADI & 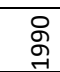 & ৪ & ஜ્ర & $\underset{\sim}{\stackrel{N}{2}}$ & $\begin{array}{l}\infty \\
\text { D्र }\end{array}$ \\
\hline 17145 - EDREMIT & $x$ & $x$ & $x$ & $x$ & $x$ \\
\hline 17722 - BURHANIYE & $x$ & $x$ & $x$ & $x$ & $x$ \\
\hline 17175 - AYVALIK & $x$ & $x$ & $\mathrm{x}$ & $\mathrm{x}$ & $\mathrm{x}$ \\
\hline 17180 - DíkiLi & $\mathrm{x}$ & $x$ & $\mathrm{x}$ & $\mathrm{x}$ & $\mathrm{x}$ \\
\hline 17742 - BERGAMA & $x$ & $x$ & $\mathrm{x}$ & $x$ & \\
\hline 4747 - KINIK & $x$ & & & & \\
\hline 5091 - ALIAĞGA & $x$ & & & & \\
\hline 4916 - ÇANDARLI & $x$ & & & & \\
\hline 4919 - YUNT DAĞI & $x$ & & & & \\
\hline 17790 - BORNOVA & $x$ & $x$ & $x$ & & \\
\hline 5758 - KEMALPAŞA & $x$ & & & & \\
\hline 17720 - IZMIR BÖLGE & $\mathrm{x}$ & $\mathrm{x}$ & $\mathrm{x}$ & & \\
\hline 9020 - MENEMEN TOP SU & $x$ & & & & \\
\hline 9006 - ÇAMALTI TUZLASI & $\mathrm{x}$ & $x$ & & & \\
\hline 17221 - ÇEŞME & $\mathrm{x}$ & $\mathrm{x}$ & $\mathrm{x}$ & $\mathrm{x}$ & $x$ \\
\hline 5956 - URLA & $x$ & & & & \\
\hline 17820 - SEFERIHISAR & $\mathrm{x}$ & $x$ & $x$ & $x$ & $x$ \\
\hline 5962 - DAĞKIZILCA & $\mathrm{x}$ & & & & \\
\hline 6296 - TORBALI & $x$ & & & & \\
\hline 6294 - DEĞiRMENDERE & $\mathrm{x}$ & & & & \\
\hline 17854 - SELÇUK & $x$ & $x$ & $x$ & $x$ & $x$ \\
\hline 730 - TiRE & $\mathrm{x}$ & & & & \\
\hline 17822 - ÖDEMiş & $x$ & $x$ & $x$ & $x$ & $x$ \\
\hline 6304 - OVAKENT & $x$ & & & & \\
\hline 17232 - KUŞADASI & $x$ & $x$ & $\mathrm{x}$ & $x$ & $x$ \\
\hline 6992 - KOÇARLI & $x$ & & & & \\
\hline 17234 - AYDIN & $\mathrm{x}$ & $\mathrm{x}$ & $\mathrm{x}$ & $\mathrm{x}$ & \\
\hline 17850 - SULTANHISAR & $x$ & & & $x$ & $x$ \\
\hline 6822 - UMURLU & $x$ & & & & \\
\hline
\end{tabular}

\begin{tabular}{|c|c|c|c|c|c|}
\hline 17860 - NAZíLLi & $\mathrm{x}$ & $\mathrm{x}$ & $\mathrm{x}$ & $\mathrm{x}$ & $\mathrm{x}$ \\
\hline 6825 - YENIPAZAR & $x$ & & & & \\
\hline 6657 - KUYUCAK & $\mathrm{x}$ & & & & \\
\hline 17223- DiDiM & $\mathrm{x}$ & $\mathrm{x}$ & $\mathrm{x}$ & $\mathrm{x}$ & $\mathrm{x}$ \\
\hline 4575 - SOMA & & $\mathrm{x}$ & & & \\
\hline 17219 - ADNAN MEND. HAVA LM. & & $\mathrm{x}$ & $x$ & $x$ & \\
\hline 17782- FOÇA TOPRAK SU & & & & $\mathrm{x}$ & $\mathrm{x}$ \\
\hline 17789 - MENEMEN & & & & $\mathrm{x}$ & \\
\hline 17218 - ÇiĞLI HAVALIMANI & & & & $x$ & \\
\hline 17225 - KAKLIÇ HAVALIMANI & & & & $x$ & \\
\hline 17749 - KEMALPAŞA & & & & $x$ & \\
\hline 17821 - IZMiR GAZIEMIR & & & & $x$ & \\
\hline 17790 - ALIAĞA & & & $x$ & $x$ & \\
\hline 17881 - SÖKE & & & & $x$ & \\
\hline 17227 - ÇILDIR HAVALIMANI & & & & $\mathrm{x}$ & \\
\hline 18901 - DiKiLi/ÇUKURALAN & & & & & $\mathrm{x}$ \\
\hline 18917 - KINIK & & & & & $\mathrm{x}$ \\
\hline 18040 - SOMA & & & & & $\mathrm{x}$ \\
\hline 17790 - ALİAĞA & & & & & $\mathrm{x}$ \\
\hline 17444 - KARABURUN MEND. & & & & & $\mathrm{x}$ \\
\hline 17446 - KARŞIYAKA & & & & & $\mathrm{x}$ \\
\hline 18028 - URLA & & & & & $\mathrm{x}$ \\
\hline 18443 - BUCA & & & & & $\mathrm{x}$ \\
\hline 19134 - KEMALPAŞA/BAĞYURDU & & & & & $x$ \\
\hline 18439 - KEMALPAŞA/OVCIK & & & & & $\mathrm{x}$ \\
\hline 18030 - TORBALI & & & & & $x$ \\
\hline 18049 - BAYINDIR & & & & & $\mathrm{x}$ \\
\hline $180229-$ TIRE & & & & & $\mathrm{x}$ \\
\hline 18050 - MENDERES/GÜMÜLDÜR & & & & & $\mathrm{x}$ \\
\hline 18441 - BEYDAĞ & & & & & $\mathrm{x}$ \\
\hline 18426 - GERMENCIK & & & & & $\mathrm{x}$ \\
\hline 18439 - KUYUCAK & & & & & $x$ \\
\hline
\end{tabular}

Arazi kullanımının belirlenmesi aşamasında ise 1990, 2000, 2006 ve 2012 yılları için Avrupa Konseyi tarafından koordine edilen Kopernik Programı veritabanından indirilen CORINE (Coordination of Information on the Environment) arazi örtüsü haritaları kullanılmıştır. CORINE projesi 1985 yılında Avrupa Birliği tarafından başlatılmıştır. 1:100.000 ölçeğinde ve uydu görüntüleri ile topoğrafik haritalar kullanılarak üretilmektedir (3). 2018 yılı için CORINE arazi örtüsü haritaları kapsamına Türkiye dahil edilmemiş olduğundan bu yıla ait arazi kullanım haritası için Amerika Birleşik Devletleri Jeoloji Araştırmaları Kurumu veritabanından elde edilen LANDSAT 8 uydu görüntüleri kullanılmıştır (2, 2019). Bu görüntülere ait bilgiler Çizelge 3 ve Çizelge 4 'te verilmektedir. 
Çizelge 3. Kullanılan görüntülere ait bilgiler.

\begin{tabular}{|c|c|c|c|}
\hline $\begin{array}{l}\text { Görüntü } \\
\text { Tarihi }\end{array}$ & Landsat Ürün Kimliği & $\begin{array}{l}\text { Uydu, } \\
\text { Sensör } \\
\text { Tipi }\end{array}$ & $\begin{array}{l}\text { Bulut } \\
\text { Oranı }\end{array}$ \\
\hline 10.06 .2018 & $\begin{array}{c}\text { LC08_L1TP_180033_20180610_ } \\
\text { 20180615_01_T1 }\end{array}$ & $\begin{array}{c}\text { Lands } \\
\text { at 8, } \\
\text { OLI_TI } \\
\text { RS }\end{array}$ & 0,40 \\
\hline 10.06 .2018 & $\begin{array}{c}\text { LC08_L1TP_180034_20180610_ } \\
\text { 20180615_01_T1 }\end{array}$ & $\begin{array}{c}\text { Lands } \\
\text { at } 8 \text {, } \\
\text { OLI_TI } \\
\text { RS }\end{array}$ & 1,52 \\
\hline 03.07.2018 & $\begin{array}{c}\text { LC08_L1TP_181033_20180703_ } \\
\text { 20180717_01_T1 }\end{array}$ & $\begin{array}{c}\text { Lands } \\
\text { at } 8 \text {, } \\
\text { OLI_TI } \\
\text { RS }\end{array}$ & 0,01 \\
\hline
\end{tabular}

Çizelge 4. Kullanılan görüntülere ait bilgiler.

\begin{tabular}{ll}
\hline Band Sayısı & 11 \\
\hline Harita Projeksiyonu & UTM \\
\hline Datum & WGS84 \\
\hline Elipsoid & WGS84 \\
\hline UTM_Zone & 35 \\
\hline Hücre Boyutu (PAN) & 15 \\
\hline Hücre Boyutu (MS) & 30 \\
\hline
\end{tabular}

Biyoklimatik Konfor ve Arazi Kullanımı Arasındaki İlişkinin temel mekânsal analiz yöntemlerinin kullanılarak incelenen bu çalışmanın yöntemini oluşturan başlıca işlemler şunlardır; FES değerlerinin, konfor ve arazi kullanım haritalarının elde edilmesi veile biyoklimatik konfor ve arazi kullanımı ilişkisininaçıklanması işlemleri.

FES değerlerinin elde edilebilmesi için öncelikle İzmir ve çevresinde bulunan meteoroloji istasyonlarından alınan günlük ortalama sıcaklık, bağıl nem ve rüzgâr ölçüm değerleri kullanılarak RayMan programı aracılığıyla FES hesabı yapılmıştır. Şekil 8'de verilen analiz aşamaları kullanılmıştır.

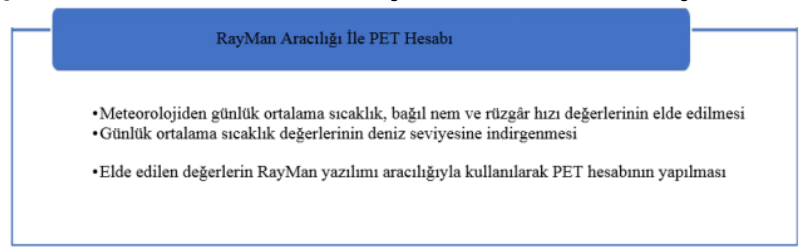

Şekil 8. FES(PET) hesabı.
FES hesabı için öncelikle istasyonların günlük sıcaklık, nem ve rüzgar verileri elde edilmiştir. Günlük verilerin aritmetik ortalaması alınarak dört mevsim ve yıllık ortalamalar haline getirilmiş, sıcaklık değerleri deniz seviyesine Denklem (1)'de belirtilen formül ile indirgenmiştir (Erdoğan, Ö., Çabuk, A., Memlük, Y., Perçin, H.,2013).

$T d=T i+(h i * 0.005) \quad$ (1)

$\mathrm{T}_{d} \quad$ : Deniz seviyesine indirgenmiş sıcaklık

$T_{i} \quad$ : Istasyonun ortalama sıcaklığı

$h_{i} \quad$ : İstasyonun yüksekliği

$\mathrm{Bu}$ işlemler sonucunda elde edilen mevsimlik ve yıllık sıcaklık, rüzgar ve nem verileri ve RayMan Pro yazılımı kullanılarak sırasıyla 1990, 2000, 2006, 2012, 2018 yılları için dört mevsim ve yıllık FES değerleri hesaplanmıştır. RayMan Pro yazılımında kullanılacak olan kişisel fizyolojik bilgiler ise her yıl için sabit olmak kaydıyla Şekil 9'da belirtildiği şekilde kullanılmıştır.

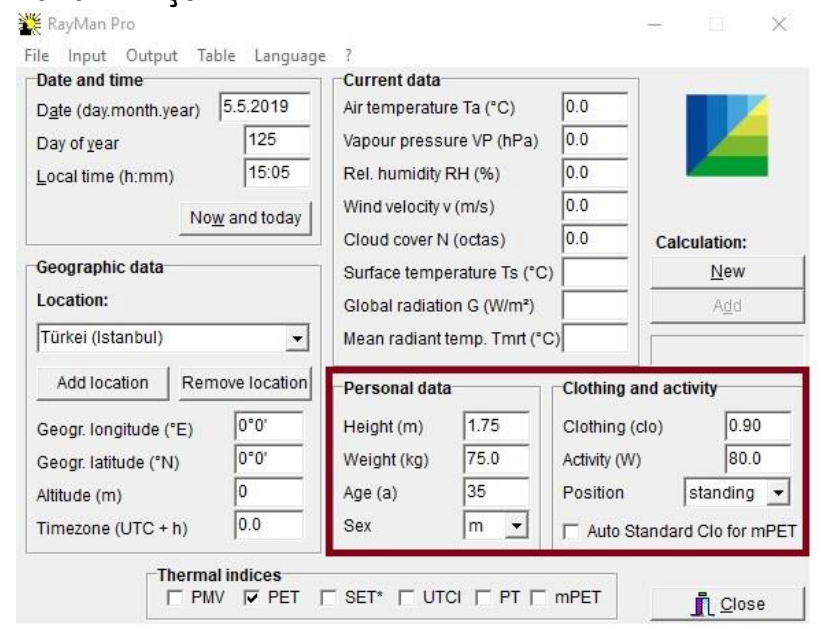

Şekil 9. RayMan Pro yazııımında kullanılan sabit değerler.

Konfor haritaları oluşturulurken RayMan programı ile üretilen FES değerleri kullanılarak ArcGIS yazılımı ile 1990, 2000, 2006, 2012, 2018 yılları için dört mevsim ve yıllık konfor haritaları üretilmiştir. Şekil 9'da konfor haritalarının oluşturulması aşamaları ifade edilmektedir.

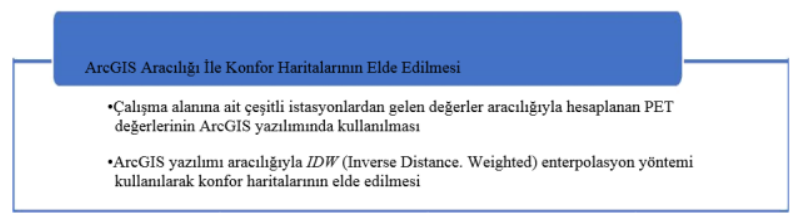

Şekil 10. Konfor haritalarının oluşturulması aşamaları.

Çalışma alanına ait FES değerleri ArcGIS yazııımında kullanılarak 1990, 2000, 2006, 2012 ve 2018 yılları için yıllık ve dört mevsimlik FES sıcaklık haritası elde edilmiş ve Inverse Distance Weighted (IDW) 
yöntemi ile enterpole edilmiştir. Şekil 11 'daebelirtilen istasyonları kullanmak kaydıyla doğruluk analizleri yapılmıştır. Her yıl ve dört mevsim için yapılan IDW analizlerinin doğrulukları regresyon analizi ile yapılmıştır. Ardından Dem verisi üzerinde Raster Calculator aracılığı ile hesaplama yapılarak öncesinde indirgenmiş sıcaklık kullanılarak elde edilen haritanın yükseltiye bağı sıcaklığı hesaplanarak sonuç haritası elde edilmiştir. Elde edilen haritalar biyoklimatik konfor aralıklarına göre sınıflandırılmıştır.

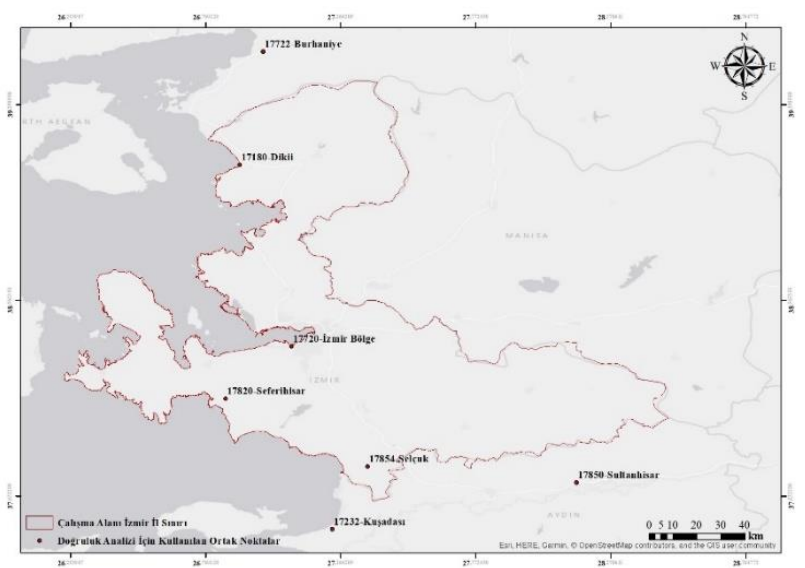

Şekil 11. Doğruluk analizinde kullanılan ortak istasyonlar.

Arazi kullanımının belirlenmesi aşamasında 1990, 2000, 2006 ve 2012 yılları için CORINE arazi örtüsü haritaları kullanılmıştır. Çalışmanın yapıldığı tarihte 2018 yılı için CORINE arazi örtüsü haritası henüz yayınlanmamış olduğundan bu yıla ait arazi kullanımları, Landsat 8 uydu görüntüleri üzerinde kontrollü sınıflandırma yapılarak belirlenmiştir.

Arazi kullanım haritalarının oluşturulmasındaki işlem adımları aşağıda maddeler halinde verilmektedir.

- 2018 yılına ait uydu görüntülerinin mozaiklenmiştir.

- Çalışma alanının büyük olması ve içerisine kentsel alanında yer alması sebebiyle yüksek mekansal çözünürlük elde edilmeye çalışılmıştır. 30 m mekânsal çözünürlüğe sahip mozaik görüntülerin, görüntü keskinleştirme işlemine tabi tutularak $15 \mathrm{~m}$ mekânsal çözünürlüğe çıkarılmıştır.

- CÇözünürlüğü arttırılmış uydu görüntüleri üzerinde kontrollü sınıflandırma işlemi yapılması

- Sınıflandırılmış görüntünün doğruluk analizinin yapılmıştır.

- Doğruluğu $\% 80$ üzerinde olan sınıflandırılmış görüntü sınıfları baz alınarak CORINE arazi örtüsü haritalarının yeniden sınıflandırılmışve çıktılar hazırlanmıştır.

\section{Bulgular}

3.1 1990, 2000, 2006, 2012 ve 2018 yılları için yıllık mevsimlik biyoklimatik konfor haritaları

Yapılan analizler sonucunda 1990 yılı yılllık biyoklimatik konfor haritası incelediğinde FES değerlerinin serin ve hafif ılık aralığında değişiklik gösterdiği anlaşılmaktadır. Çiğli, Konak, Gaziemir, Urla ile Aydın sınırına yakın olan ilçelerden Ödemiş, Torbalı ve Tire'de konforlu alanlar ağırlık olarak yer almaktadırlar. Karaburun taraflarında ise serin alanlar bulunduğu görülmektedir. Buna ek olarak, Bornova civarında indeks değerlerinin diğer alanlardan yüksek ve hafif ılık şeklinde bulunduğu anlaşılmıştır. Aydın'da yer alan istasyonların noktasal konumlarına bağlı olarak hesaplanan indeks değerlerinin diğer istasyonlara göre fazla olduğu ve yıllık konfor haritasında bu bölgelerin konforlu olarak gözüktüğü sonucuna varılmıştır. Fakat bölgenin coğrafi yapısı itibariyle dağlar denize dik uzandığından buradaki FES değerlerinin iç kesimlere fazla nüfuz etmediği kanısına ulaşılmıştır. Bu sonuçlar Şekil 12'de yer alan mevsimlik haritalarda daha net görülmektedir. Sonuç itibariyle, 1990 yılında FES değerlerinin yerleşim yoğunluğunun ve yapılaşmanın çok olduğu lokasyonlarda daha fazla çıktığı anlaşıımıştır.

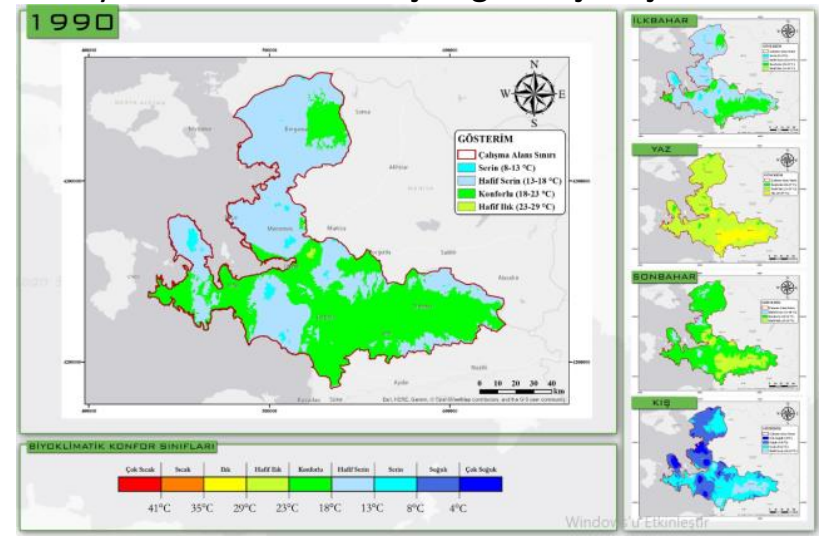

Şekil 12. 1990 yılı biyoklimatik konfor haritası.

2000 yılında, mikro ölçekte Konak ve Bayraklı bölgesindeki FES değerlerinin İzmir'in diğer merkezi yerleşim yerlerinden fazla olduğu Şekil 13 'te hem yıllık hem de mevsimlik haritalarda net olarak gözükmektedir. Ayrıca, 1990 yılında olduğu gibi Aydın sınırına yakın olan bölgedeki indeks değerlerinin de fazla olduğu fakat bunların iç kesimlere ulaşamadığı görülmektedir. Aynı şekilde Karaburun civarının diğer bölgelere göre de soğuk olduğu kanısına ulaşılmıştır. 


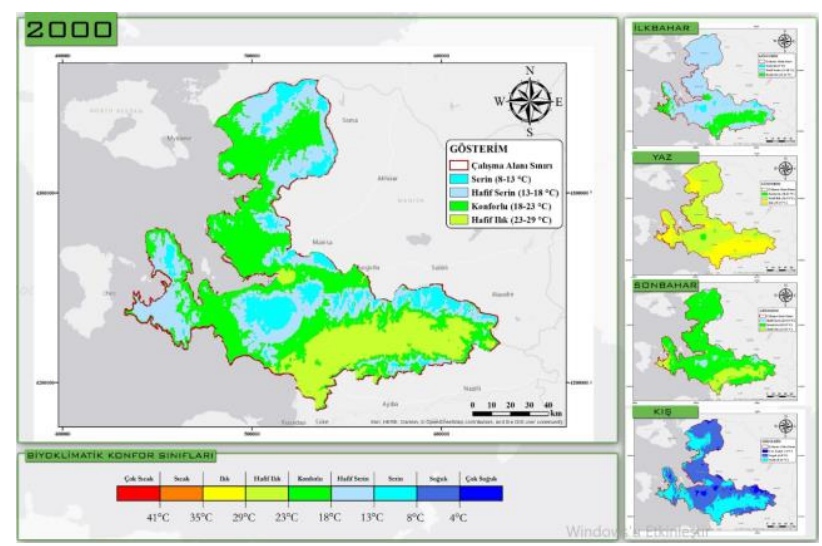

Şekil 13. 2000 yıllık ve mevsimlik biyoklimatik konfor haritası.

Şekil 14'te görülen 2006 yılının haritaları incelendiğinde, önceki yıllara göre genel olarak bir soğuma trendi oluştuğu anlaşılmıştır. Yıllık biyoklimatik konfor haritasında konforlu alanların Gaziemir ve havalimanı civarlarında bölgesel olarak yer aldığı görülmüştür. İlgili bölgelerde hem yıllık hem de mevsimlik haritalarda indeks değerlerinin diğer alanlara kıyasla daha fazla olduğu sonucuna varılmıştır. İzmir genelinde ise alansal bağlamda konforlu bölgelerin en fazla olduğu mevsim ise yaz olmuştur.

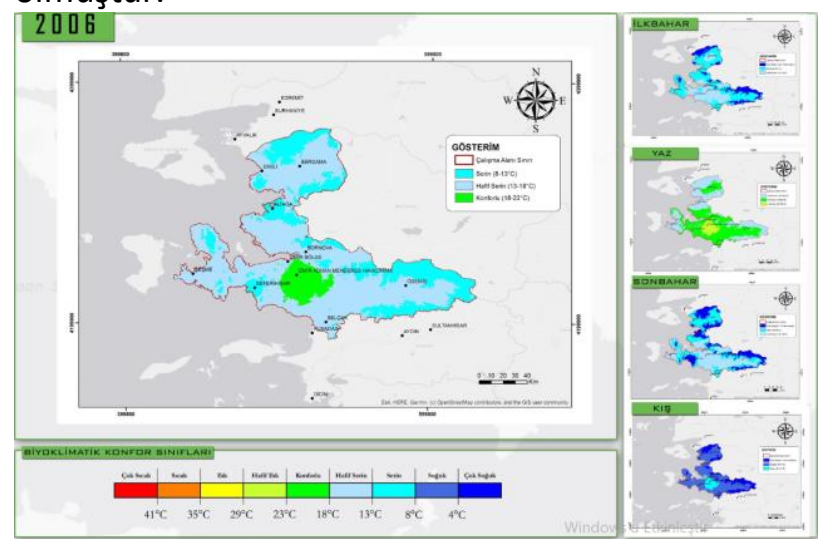

Şekil 14. 2006 yılı yıllık ve mevsimlik biyoklimatik konfor haritası.

Şekil 15'te yer alan haritalarda 2012 yılında, İzmir kent merkezinde Konak ve Balçova'da konforlu bölgeler yer alırken, yerleşimin ve kentleşmenin yoğun olduğu diğer bölgeler hafif serin şeklinde görülmüştür. Aydın sınırına yakın ilçelerden Ödemiş, Tire ve Torbalının yer aldığı üçgende ise konforlu alanların ağırlıklı olarak yer aldığı anlaşılmıştır. Aynı şekilde, mevsimlik haritalarda da Konak, Balçova, Ödemiş, Tire ve Torbalı'nın bulunduğu alanların daha sıcak olduğu kanısına varılmıştır.
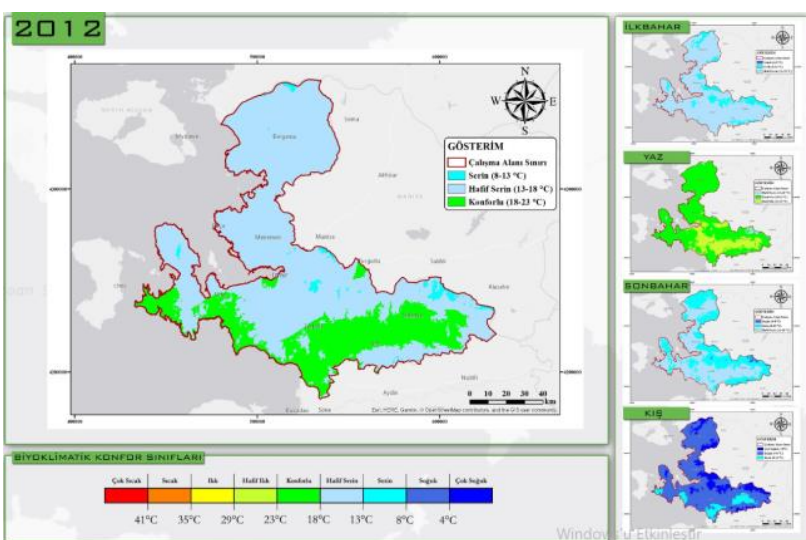

Şekil 15. 2012 yılı yıllık ve mevsimlik biyoklimatik konfor haritası.

Şekil 16'da yer alan haritalarda 2018 yılında tıpkı 2006 'da olduğu gibi bir soğuma trendi gözlemlenmiştir. Yıllık FES haritasında hiç konforlu alan yer almazken, çalışma alanı genelinin ağırlıklı olarak serin gözüktüğü anlaşılmıştır. Ödemiş ilçesinin yer aldığı konumda indeks değerlerinin hem yıllık hem de mevsimlik haritalarda fazla çıktığı görülmüştür. En konforlu ayın ise çalışma alanı genelinde sonbahar olduğu bulunmuştur.

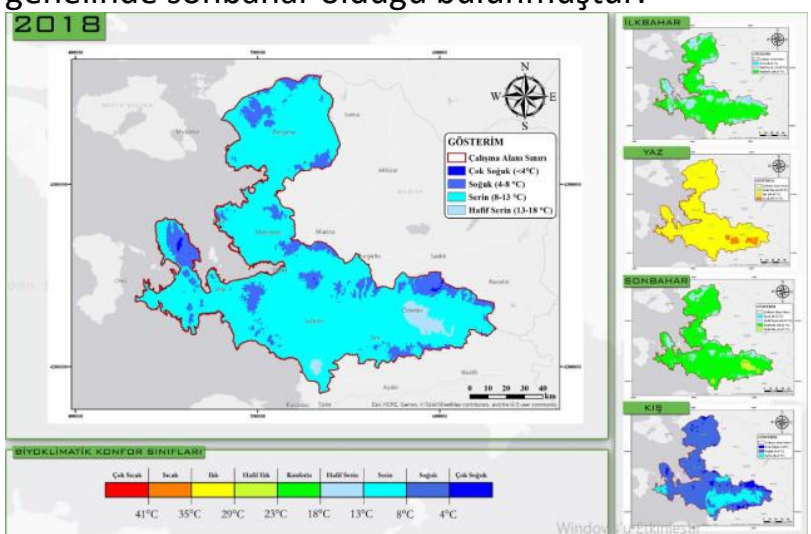

Şekil 16. 2018 yılı yıllık ve mevsimlik biyoklimatik konfor haritası.

\subsection{Arazi kullanım haritalarının oluşturulması}

Arazikullanımının sınıflarının belirlenmesi aşamasında CORiNE arazi örtüsü sınıfları çalışmanın daha anlaşııır ve açık olması açısından Şekil 17'deki gibi düzenlenmiştir. 


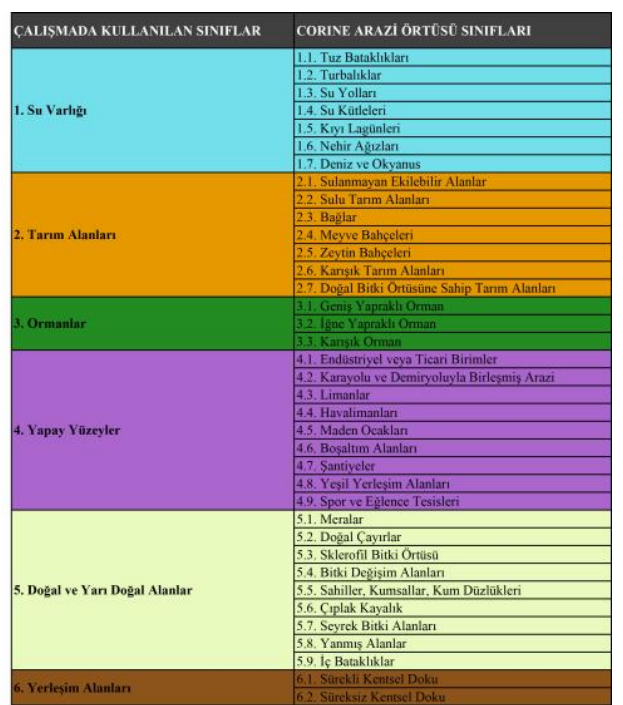

Şekil 17. CORINE Arazi örtüsü sınıfları

Sınıfları düzenlenen CORINE arazi örtüsü haritaları 1990, 2000, 2006 ve 2012 yılları için sırasıyla Şekil 18 , Şekil 19, Şekil 20 ve Şekil 21'de görülmektedir. 2018 yılı için Landsat 8 uydu görüntüleri üzerinde kontrollü sınıflandırma yapılarak elde edilen harita Şekil 21'de görülmektedir.

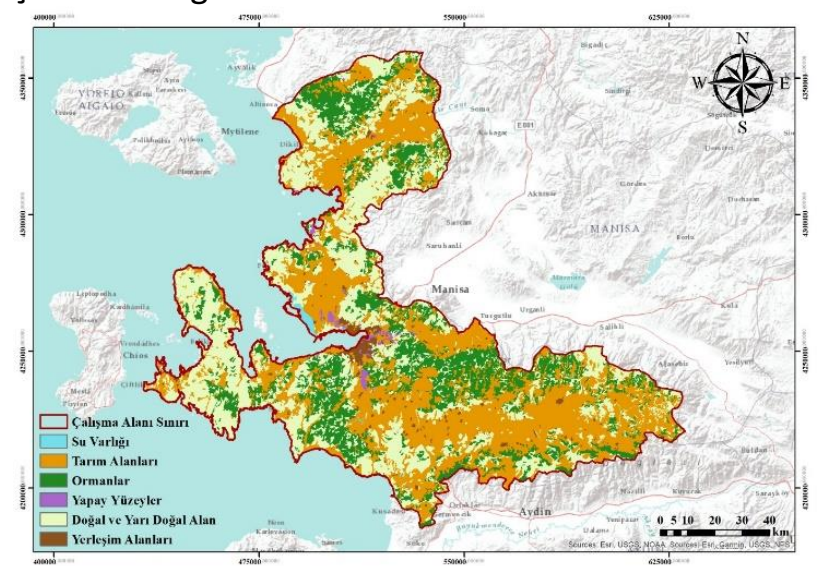

Şekil 18. 1990 Yılı CORINE arazi örtüsü haritası.

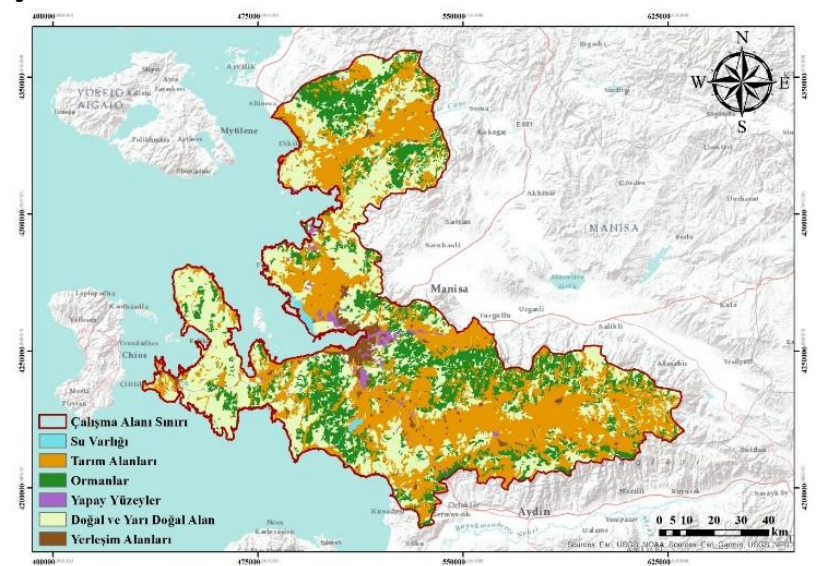

Şekil 19. 2000 yılı CORINE arazi örtüsü haritası.

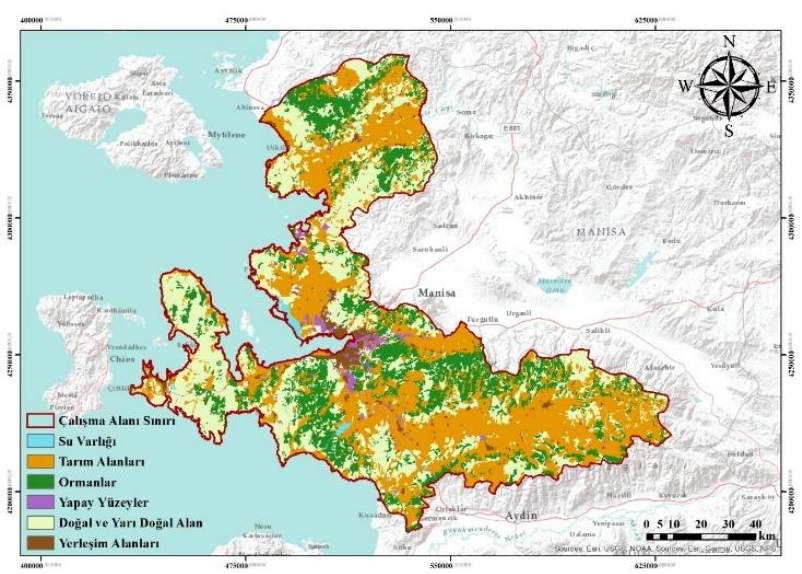

Şekil 20. 2006 yılı CORINE arazi örtüsü haritası .

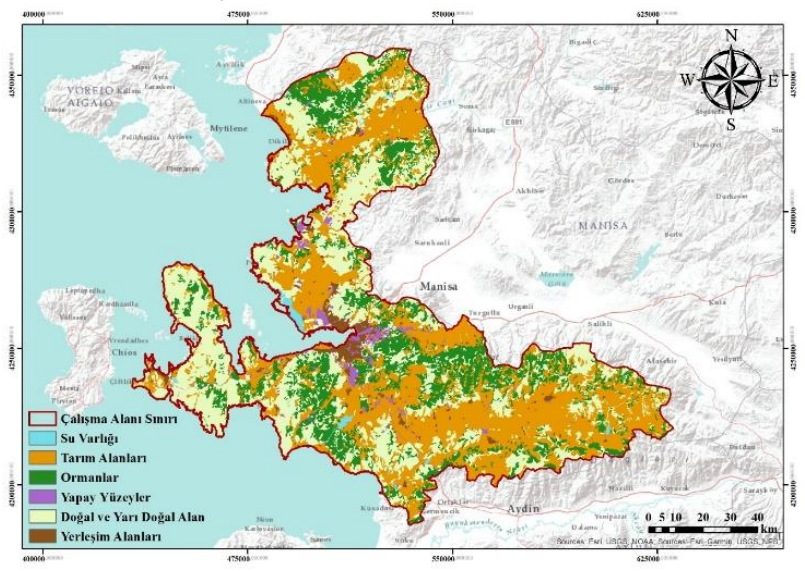

Şekil 21. 2012 yılı CORINE arazi örtüsü haritası.

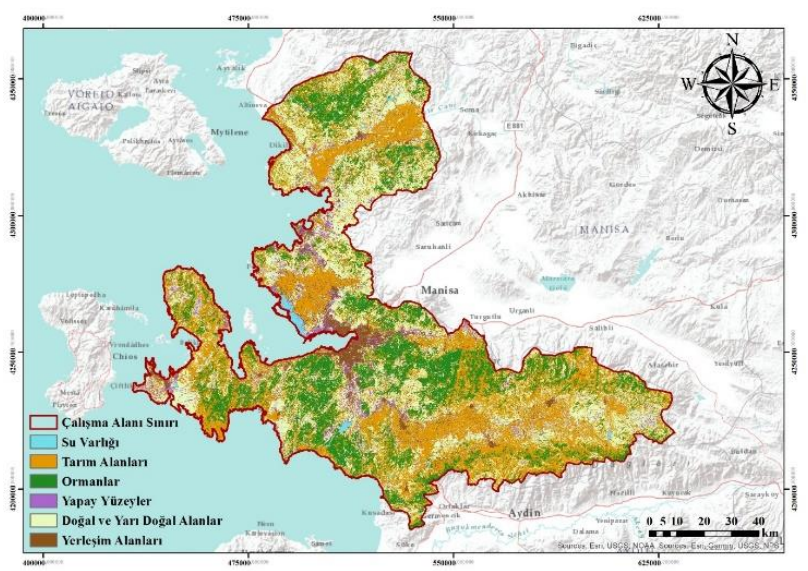

Şekil 22. 2018 yılı arazi örtüsü haritası.

Şekil 23'de görüldüğü gibi İzmir şehrinin yıllara göre arazi arazi kullanımları incelendiğinde ise yerleşim alanlarının ve yapay yüzeylerin arttığı tarım alanlarının ise azaldığı görülmüştür. Orman alanları ile doğal ve yarı doğal alanların yıllar içinde artma ve azalma olarak değiştiği görülmüştür. 


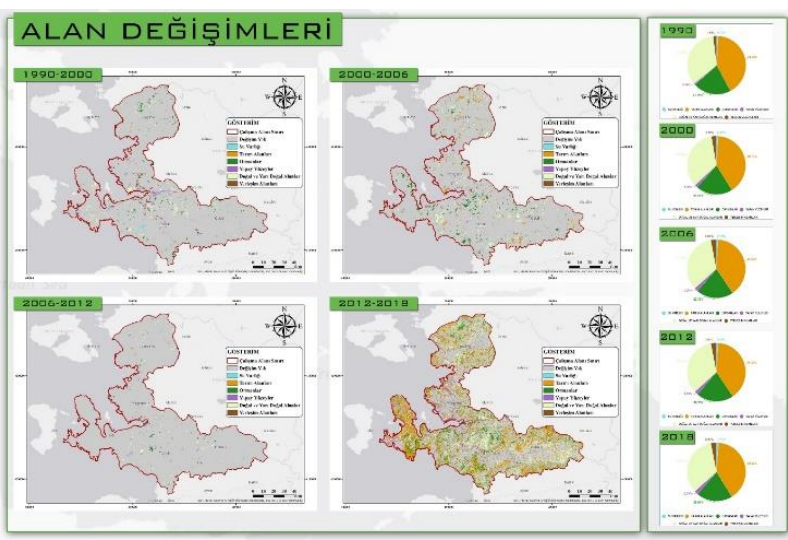

Şekil 23. Yıllara göre arazi örtüsündeki farklar.

\subsection{Biyoklimatik konfor haritaları ve arazi kullanım ilişkisi}

Yıllık biyoklimatik konfor haritaları ve arazi kullanım ilişkisi incelenirken şehirin konfor bölgeleri içinde kalan bölge ile bu bölge içinde yer alan arazi kullanım alanlarına bakıımıştır.

Şekil 24'te görüldüğü gibi 1990 yılı biyoklimatik konfora uygun alanlar içerisine arazi kullanım durumlarına bakıldığında bölgenin \%57'sinin tarım alanlarından, $\% 25^{\prime}$ inin doğal ve yarı doğal alanlardan ve \%14'ünün orman alanlarından oluştuğu görülmüştür.

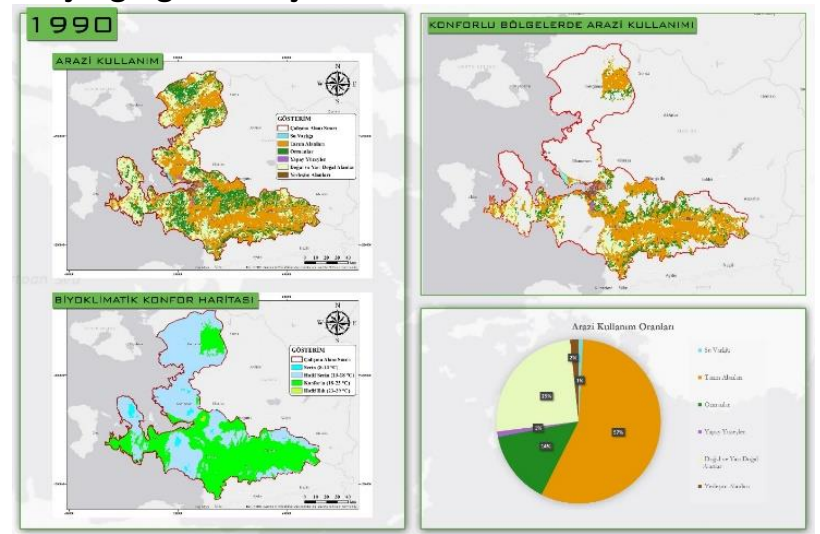

Şekil 24. 1990 yılı biyoklimatik konfor haritası ve arazi kullanım ile ilişkisi.

Şekil 25'de görüldüğü gibi 2000 yılı biyoklimatik konfora uygun alanlar içerisine arazi kullanım durumlarına bakıldığında bölgenin \%57'sinin tarım alanlarından, \%26'sının doğal ve yarı doğal alanlardan ve \%13'ünün orman alanlarından oluştuğu görülmüştür.

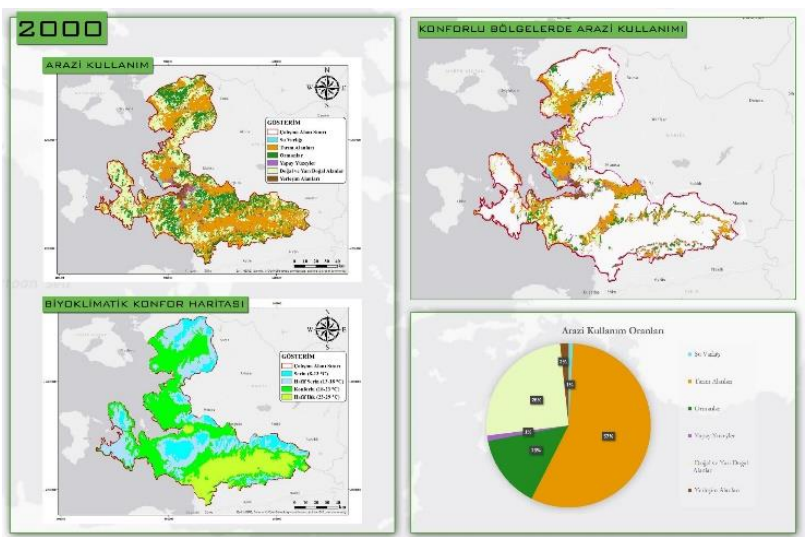

Şekil 25. 2000 yılı biyoklimatik konfor haritası ve arazi kullanım ile ilişkisi.

Şekil 26'da görüldüğü gibi 2006 yılı biyoklimatik konfora uygun alanlar içerisine arazi kullanım durumlarına bakıldığında bölgenin \%47'sinin tarım alanlarından, \%18'inin doğal ve yarı doğal alanlardan ve \%18'ünün orman alanlarından oluştuğu görülmüştür.

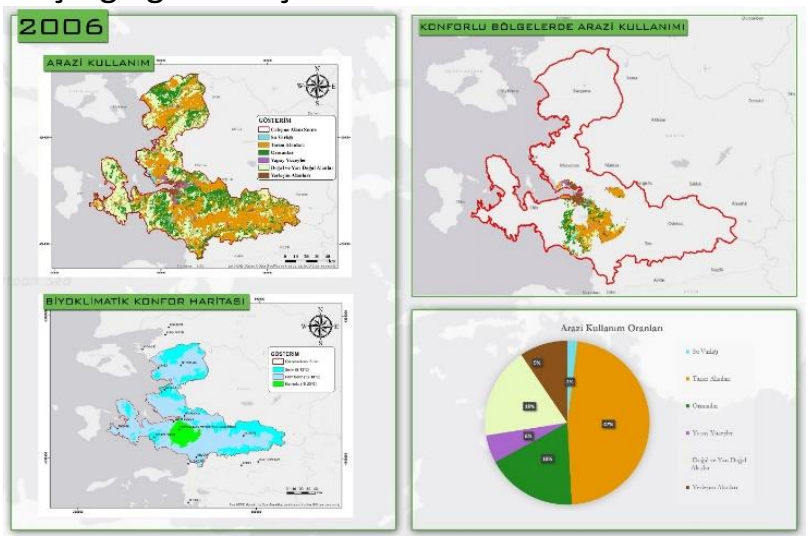

Şekil 26. 2006 yılı biyoklimatik konfor haritası ve arazi kullanım ile ilişkisi.

Şekil 27'de görüldüğü gibi 2012 yılı biyoklimatik konfora uygun alanlar içerisine arazi kullanım durumlarına bakıldığında bölgenin \%58'sinin tarım alanlarından, \%29'unun doğal ve yarı doğal alanlardan ve $\% 8^{\prime}$ ünün orman alanlarından oluştuğu görülmüştür.

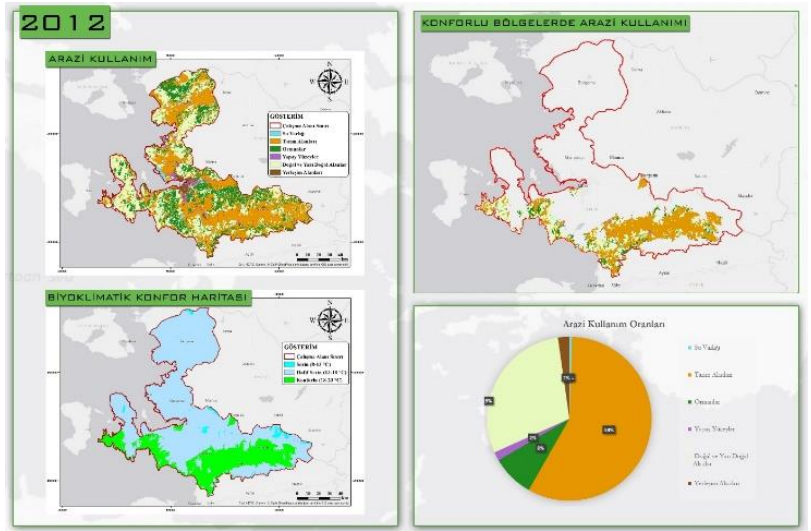

Şekil 27. 2006 yılı biyoklimatik konfor haritası ve arazi kullanım ile ilişkisi. 
2018 yılında biyoklimatik konfor alanları olmadığı için herhangi bir karşılaştırma yapılamamıştır. 2018 yılı biyoklimatik konfor haritası ve arazi kullanımı Şekil 28 ' da görüldüğü gibidir.

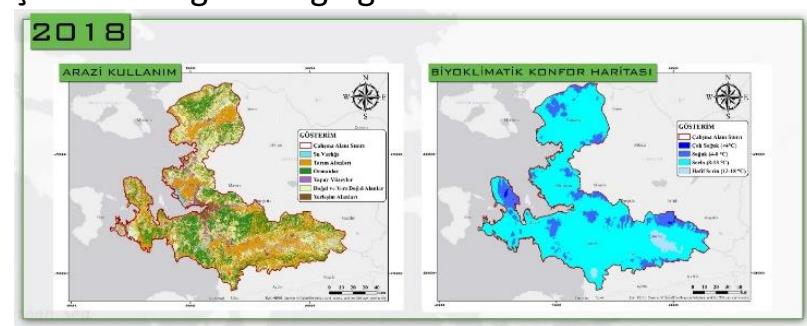

Şekil 28. 2018 yılı biyoklimatik konfor haritası ve arazi kullanımı.

\section{Tartışma ve Sonuç}

1990, 2000, 2006, 2012 ve 2018 yıllarına ait Biyoklimatik Konfor Haritaları ile Arazi Kullanım Haritaları incelenmiş olup İzmir şehrinin konfor bölgelerinin büyük bir çoğunluğunun tarım alanlarından daha sonra sırasıyla doğal ve yarı doğal alanlardan, orman alanlarından ve yerleşim yerlerinden oluştuğu gözlemlenmiştir.

Yerleşim yerlerinin biyoklimatik konfor alanı içinde yer alması yapılaşma ile birlikte ilgili alanlarda sıcaklık artışlarının meydana geldiğini göstermektedir. Yapılaşma ile birlikte kullanılan malzemeler yerleşim yerlerindeki yansıma (albedo) değerlerini arttırarak havaya salınan zararlı gazlar ile birlikte ısı adalarının oluşmasına neden olmaktadır. Kentlerde kullanılan malzemelerin ya da yapılan kentsel tasarımın albedo değerlerini düşürmeye yönelik olmaması buralardaki ISI adalarının kümeleşerek yıllar içerisinde daha da artmasına ve gece ile gündüz arasındaki sıcaklık farkının azalmasına neden olmaktadır. Bu da yerleşim alanlarının sıcaklıkların yıllar içerisinde artmasına neden olmaktadır. İzmir illinde nem miktarının oldukça yüksek olması ve kent merkezinde gözlenen çarpık kentleşme nedeniyle rüzgârın kenti soğutma etkisinin kullanılamaması zamanla bu bölgenin konfor bölgesinden çıkarak fazla ısınacağını göstermektedir.

Orman alanları kapladığı alan içerisinde gündüz sıcaklığını düşürerek gece sıcaklıklarını yükseltici etki sağlamaktadır. Aynı şekilde sıcak mevsimlerde hava sıcaklığını düşürerek kış mevsiminde sıcaklığı yükseltici etkisi bulunmaktadır. Bu durumdan kaynaklı orman alanlarında sıcaklık farkları toprak alanlara göre çok olmamakla birlikte kentsel ISI adalarına kıyasla daha fazla olmaktadır.

Tarım alanları ile doğal ve yarı doğal alanların konfor bölgesi içerisinde yer alması, toprağın albedo değerinin yerleşim alanlarına kıyasla daha yüksek olmasının etkisi olduğunu göstermektedir. Fakat bu durum kentsel alanlarda ISI adaları oluşurken toprağın olduğu alanlarda böyle bir durumun söz konusu değildir. Bu sebeple havada tutulan bir ISI kümesi bulunmamakta ve gece olduğunda sıcaklık değerleri doğal bir şekilde düşmektedir. Toprağın yer aldığı alanlarda gece ve gündüz sıcaklarını arasındaki farkın diğer arazi kullanımlarına göre fazla olması biyoklimatik konfor bölgelerini olumsuz etkilememiş hatta daha konforlu olarak çıkarmıştır. Bunun nedeni de İzmir şehrinde görülen yüksek nemin hissedilen sıcaklık değerini arttırarak konfor alanlarına olumsuz etkisinin olmasıdır. Toprak alanlarında meydana gelen bu ısı farkları İzmir gibi nemli şehirlerde kentin konforunu arttıran bir etmen olarak saptanmıştır. Ayrıca konfor bölgesi olan bu alanların büyük bir çoğunluğu Bozdağlar ve Aydın Dağları arasında bulunmaktadır. İki dağın arasında bulunan bu alanın en önemli özelliği hava akışının bozulmadan sağlanarak rüzgârın soğutma etkisiyle hissedilen sıcaklığın daha düşük olmasıdır. Yıllar içerisinde azalan biyoklimatik konfor bölgelerinin arttırılması için öncelikle yeni yapılacak yerleşim yerlerinde bölgenin iklimine uygun yapılaşma tercih edilmelidir. Önceden yapılaşmış çevre için ise albedo değerlerini en aza indirecek şekilde kentsel peyzaj planlaması yapılmalıdır. Kente hakim olan rüzgar yönü kullanılarak kentteki ISI adasınındağııı Iması amaçlanmalıdır. Bu ısı adalarının kontrolü ve zararlı gazların temizlenmesi içinde kent içerisinde ve özellikle kent çeperinde orman sahaları arttırılmalıdır. Çalışma alanı genelinde ise bölgenin topografyasının en iyi şekilde kullanılarak plan kararları alınmalıdır. Tarım alanlarında meydana gelen parçalanma azaltılarak toprak alanlarının daha bütüncül olarak ele alınması sağlanmalıdır. Yine il genelinde orman alanları parçalı olarak dağılmamalı ve ekim yapılırken diğer illerle birlikte ekolojik ağ, yeşil koridor oluşturulacak şekilde planlanmalıdır. Literatürde bulunan çalışmalar incelendiğinde İzmir ili özelinde yapılan çalışmalar oldukça azdır. Ülkemizde yapılan diğer çalışmaların büyük kısmında ise biyoklimatik konfor konusunu tek bir yıl için incelemişlerdir. Ayrıca, biyoklimatik konfor bölgelerini de arazi kullanımları ile ilişkilendirerek araştıran bir çalışma bulunmamaktadır. Tüm bunlara ek olarak,literatürde yer alan bazı çalışmalarda indeks ve sıcaklık değerlerinin yüksekliğe bağlı olarak indirgenmediği de görülmüştür. Bu durumun çalışmanın sonucunu ve doğruluğunu olumsuz etkileyeceği göz önünde bulundurulmalıdır (Çetin vd., 2010; Kestane ve Ülgen 2013; Çetin, 2016; Özşahin ve Eroğlu, 2018). 
Kestane ve Ülgen (2013), İzmir ili için yaptıkları çalışmada sadece İzmir ili içerisindeki meteoroloji istasyonu verilerini kullanmışlardır. Oysa enterpolasyon işleminde İzmir iline sınır olan çevre illerin de meteoroloji istasyonu verilerini kullanmak çalışmanın doğruluğunu artıracaktır. Bu çalışmada, sadece izmir ili içerisinde yer alan meteoroloji istasyonları verileri değil, aynı zamanda Balıkesir, Aydın ve Manisa illerinin İzmir iline yakın olan meteoroloji istasyonları verileri de kullanılmıştır.

İnsan biyoklimatik konforu üzerine yapılan çalışmalarda genellikle bir bölgeye ait biyoklimatik konfor şartlarının yıl içindeki dağılımlarının bulunması amaçlanmaktadır. Turizm, rekreasyon faaliyetleri gibi dış mekanlara ait aktivitelerinin biyoklimatik konfor açısından uygun olan dönemlerde yapılması tavsiye edilir. Dış mekan planlama ve tasarımı en başta peyzaj mimarlığı meslek disiplininin ilgi alanı olduğu için, peyzaj planlaması ve tasarımı açısından arazi örtüsünün mevsimlerdeki biyoklimatik konforunu incelenmelidir. Mevsimlere göre yapılan incelemelerde şehre ait konforlu dönemler daha iyi tespit edilebilmektedir. Konforlu dönemlerin dış mekanlara ait aktiviteleri etkileyebileceği ya da alan kullanımlarının konfor bölgelerini değiştirebileceği için şehrin arazi kullanımının hangi konforlu dönemlerde yüksek olduğunun bilinmesi şehrin ileriye yönelik alacağı kentsel planlama kararlarında etkili olacağı düşünülmüştür (Yılmaz ve Toy, 2009). Ayrıca değişen yıllar içerisinde aynı mevsimler arasında iklim değişikliği veya meteorolojik faktörlere bağlı olarak sıcaklık farkı meydana gelebilmektedir. Bu durum da biyoklimatik konforu direkt olarak etkilemektedir. Bu sebepten, çalışmanın ilerleyen süreçlerinde katkı sağlayacağı düşünülerek biyoklimatik konfor bölgelerinin alansal dağılımı farklı yıllara göre mevsimsel olarak da incelenmiş ve arazi kullanımlarının konforlu dönemlere göre planlanmasına katkı sağlayabileceği fikri ile mevsimlik analizler yapılmıştır.

Sonuç olarak, İzmir şehrinin 1990, 2000, 2006, 2012 ve 2018 yıllarına ait biyoklimatik konfor bölgeleri değişimlerinin arazi kullanımları ile ilişkisi irdelendiği ve konforlu alanların artırımı için çözümler ve öneriler sunulduğu bu çalışmadaçevreyle, insanla, doğayla uyumlu sürdürülebilir kent modellerinin tasarlaması için altlık niteliğinde bir çalışma oluşturulmuştur.

\section{Teşekkür}

$\mathrm{Bu}$ çalışma Eskişehir Teknik Üniversitesi, Lisansüstü Eğitim Enstitüsü, Uzaktan Algılama ve Coğrafi Bilgi
Sistemleri Anabilim Dalı UCS637-Uzaktan Algılama ve Coğrafi Bilgi Sistemleri Stüdyosu I ve UCS638-Uzaktan Algılama ve Coğrafi Bilgi Sistemleri Stüdyosu II dersleri kapsamında üretilmiştir. Çalışma süresince eleştirileriyle çalışmaya destek veren öğretim üyelerine teşekkür ederiz.

\section{Kaynaklar}

Çalışkan, O. ve Türkoğlu, N., 2012. Türkiye'nin biyoklimatik koşullarının analizi. Coğrafi Bilimler Dergisi, 10(2), 151-164.

Çalışkan, O. ve Türkoğlu, N., 2014. Ankara'da Termal Konfor Koşulların Eğilimi Ve Şehirleşmenin Termal Konfor Koşulları Üzerine Etkisi. Coğrafi Bilimler Dergisi Cbd, 12 (2), 119-132 (2014)DOI: 10.1501/Cogbil_0000000156

Çetin, M., Topay, M., Kaya, L.G. \& Yılmaz, B., 2010. Biyoiklimsel Konforun Peyzaj Planlama Sürecindeki Etkinliği: Kütahya Örneği. Süleyman Demirel Üniversitesi Orman Fakültesi Dergisi, 1(A), 83-95.

Çetin, M., 2016. Peyzaj Planlamada Biyoklimatik Konfor Alanların Belirlenmesi: Cide Kıyı Şeridi Örneği. Türk Tarım - Gıda Bilim ve Teknoloji Dergisi, 4(9), 800804.

Daneshvar, M. R. M., Bagherzadeh, A., ve Tavousi, T., 2013. Assessment of bioclimatic comfort conditions based on Physiologically Equivalent Temperature (PET) using the RayMan Model in Iran. Central European Journal of Geosciences, 5(1), 53-60.

Demirtaş, Ö. D. (2007). İzmir Ilii İklim Parametrelerinin Değerlendirilmesi. Yüksek Lisans Tezi, Ege Üniversitesi, Fen Bilimleri Enstitüsü , Tarımsal Yapılar ve Sulama Anabilim Dalı.

Erdoğan, Ö., Çabuk, A., Memlük, Y., ve Perçin, H., 2013. Ekolojik arazi kullanım kararlarına uygun rekreasyon alanlarının AHP yöntemi kullanılarak Kütahya kenti örneğinde irdelenmesi. Harita Teknolojileri Elektronik Dergisi, 5(1),26-36.

Fröhlich, D., \& Matzarakis, A. (2017). RayMan Pro.

Güçlü, Y., 2010. Ege bölgesi kıyı kuşağında iklim konforu şartlarının kıyı turizmi yönünden incelenmesi. Uluslararası Insan Bilimleri Dergisi, 7(1), 794-823.

İzmir Büyükşehir Belediyesi (2013). 2010-2017 Stratejik Planı.Kestane, Ö., ve Ülgen, K., 2013. İzmir ili için 
biyoklimatik konfor bölgelerinin belirlenmesi. SDÜ

Teknik Bilimler Dergisi, 3(1), 18-25.

Kántor, N., Unger, J., 2010. Benefits and opportunities of adopting GIS in thermal comfort studies in resting places: An urban park as an example. Landscape and Urban Planning, 98, 36-46.

Kara, F., 2017. Spatio-Temporal Analysis of Land Cover Changes of Izmir Province of Turkey Using Landsat TM and OLI Imagery. Journal of Geography, Environment and Earth Science International, 10,4, $1-14$.

Lin, T.-P., Matzarakis, A., \& Liu, Y.-W. (n.d.). Outdoor Thermal Comfort Acceptable Range and Campus Microclimate in Hot-Humid Region. Urbanclimate. Net, 247-252.

Makaremi, N., Salleh, E., Jaafar, M. Z., \& GhaffarianHoseini, A. H. (2011). Thermal Comfort Conditions of Shaded Outdoor Spaces In Hot and Humid Climate of Malaysia. Building and Environment, 48(1), 7-14.

Özşahin, E., ve Eroğlu, İ., 2018. Tekirdağ illinde Eğitim ve Biyoklimatik Konfor Arasındaki İlişkinin Değerlendirilmesi-

Assessment of Relationship Between Education and Bioclimatic Comfort in Tekirdag Province. Kastamonu Education Journal, 26(1).

Özyavuz, M., 2017. Tekirdağ ili'nin Biyoiklimsel Konforunun Coğrafi Bilgi Sistemleri ile Analizi, NKUBAP.08GA.16.015 no'lu Namık Kemal Üniversitesi Bilimsel Araştırma Projesi.

Pawar, A. S., Mukherjee, M., ve Shankar, R., 2015. Thermal comfort design zone delineation for India using GIS. Building and Environment, 87, 193-206.

Song, Y., ve Wu, C., 2018. Examining human heat stress with remote sensing technology. GIScience \& Remote Sensing, 55(1),19-37.

Svensson, M. K., Thorsson, S., ve Lindqvist, S., 2003. A geographical information system model for creating bioclimatic maps-examples from a high, mid-latitude city. International Journal of Biometeorology, 47(2), 102-112.

Tağıl, Ş. Ve Ersayın, K., 2015. Balıkesir İlinde Dış Ortam Termal Konfor Değerlendirmesi. Uluslararası Sosyal Araştırmalar Dergisi, 8 (41).
Topay, M., 2007. The importance of climate for recreational planning of rural areas: case study of Muğla Province, Turkey. Developments in Tourism Climatology (Edited by: A. Matzarakis, CR de Freitas and D. Scott), 29-36.

Topay, M., ve Yılmaz, B., 2004. Biyoklimatik Konfora Sahip Alanların Belirlenmesinde CBS'den Yararlanma Olanakları: Muğla illi Örneği. Proceedings of 3th GIS Days in Turkey, 425-434.

Türkoğlu, N., Çalışkan, O., Çiçek, İ., ve Yılmaz, E., 2012. Şehirleşmenin biyoklimatik koşullara etkisinin Ankara ölçeğinde incelenmesi. International Journal of Human Sciences, 9(1), 933-955.

Yılmaz, S., Toy, S., 2009. Peyzaj Tasarımında Biyoklimatik Konfor ve Yaşam Mekanları İçin Önemi, Atatürk Üniv. Ziraat Fak. Dergi. 40(1), 133-139.

\section{internet kaynakları}

1- https://asterweb.jpl.nasa.gov/gdem.asp (06.05.2019)

2- https://earthexplorer.usgs.gov , (03.05.2019)

3- http://www.CORINE.itu.edu.tr (06.05.2019) 